\title{
The Upper Valdarno Plio-Pleistocene vertebrate record: an historical overview, with notes on palaeobiology and stratigraphic significance of some important taxa
}

\author{
Lorenzo Rook $(*)$, Roman Croitor $(* *)$, Massimo Delfino (***) $(* * * *)$, \\ Marco P. Ferretti $(*)$, Gianni Gallai $(*)$ \& Marco Pavia $(* * *)$
}

\section{ABSTRACT}

The Plio-Pleistocene fossiliferous mammal sites of the Upper Valdarno Basin (Tuscany, Italy) have been known since Renaissance times. Several mammal collections from there are housed at various Museums and Institutes. Various scientists or "fossil-hunters" collected all this material from Upper Valdarno over a long period of time up to the present days. We present here an overview of the history of these collections, as well as information on biochronology, taxonomy and palaeoecology on a selection of vertebrate taxa.

Key wORDS: Upper Valdarno Basin, Fossil record, PlioPleistocene, Villafranchian, Tuscany.

\section{INTRODUCTION: AN HISTORICAL PERSPECTIVE}

Among vertebrate palaeontologists, the Plio-Pleistocene vertebrate record from Upper Valdarno Basin (Tuscany, Italy) is a reference one. The Upper Valdarno Basin is renowned for the occurrence of mammal fossil bones since Renaissance times, and Upper Valdarno fossil vertebrates from this Basin have been observed, collected, discussed, and kept in different private collections of early naturalists. The significance of the fossil record from Upper Valdarno Basin in early vertebrate palaeontology is evident by the specific name "etruscus", frequently used for many Plio-Pleistocene mammalian species. Although on of the problems with "old collections" is some degree of uncertainity concerning the exact stratigraphic provenance for some fossils, the rich Upper Valdarno Basin collections are nowadays an invaluable archive of the palaeobiology, palaeoecology and biochronology of the basin and even more important, they are a reference for Plio-Pleistocene western European large mammals chronology. An historical overview on the Upper Valdarno vertebrate faunas closely involves the ancient collections and the Museum that hosts the most

(*) Dipartimento di Scienze della Terra, Università degli Studi di Firenze, via G. La Pira, 4 - 50121 Firenze (Italy). Corresponding author: phone: +39 055 2757520; fax: +39 055 218628; email: lorenzo. rook@unifi.it

$(* *)$ Center for Archaeology, Institute of Cultural Heritage, str. Stefan Cel Mare, 1 - Kishinau MD-2001 (Republic of Moldova).

$(* * *)$ Dipartimento di Scienze della Terra, Università di Torino, Via Valperga Caluso, 35 - I-10125 Torino (Italy).

$(* * * *)$ Institut Català de Paleontologia Miquel Crusafont, Universitat Autònoma de Barcelona. Edifici ICP, Campus de la UAB s/n, 08193 Cerdanyola del Vallès, Barcelona (Spain). important ones, the Florence Museum of Natural History, rooting his history in the Granducal collections (fig. 1). The history of the Geology and Palaeontology Section of the Florence Natural History Museum and his collections has been recently published by CIOPPI \& DoMINICI (2010).

Giovanni Targioni Tozzetti, a great $18^{\text {th }}$ century collector of natural objects, played a fundamental role in the modern understanding of the meaning of fossil mammals, with reference to those from Upper Valdarno Basin. Thanks to his accurate observations, he concluded that fossils are valuable evidence for understanding life in the past and, contrary to the accepted idea that the fossil elephant bones found in the Upper Valdarno Basin were the remains of Hannibal's elephants, Targioni Tozzetti was the first to recognize the true antiquity of the Tuscan elephant remains (CIOPPI \& Dominici, 2010; PALOMbo \& FERRETTI, 2005). In the first half of 1800 s, other important Tuscan scientists played an important role in the understanding of the mammal collections from Upper Valdarno Basin. Giovanni Fabbroni developed a deep interest in palaeontology, established a productive exchange with Georges Cuvier and did his best to make the great French naturalist aware of the Tuscan fossil patrimony. The importance of exchanges Cuvier took with Fabbroni are reflected in the reference work Rechérches sur les Ossemèns fossiles (CUVIER, 1812, 1821-24) where the French palaeontologist reported and described a number of fossil specimens from Upper Valdarno (CIOPPI \& DominicI, 2010).

The first descriptive notes on Upper Valdarno Basin fossil mammals are due to Filippo Nesti (fig. 2). In the first volume of the Annals of the Florence Museum, NESTI (1808) described and illustrated fossilized "mastodont" (Anancus arvernenis) and elephant bones of the Upper Valdarno Basin (fig. 3), and in subsequent works, he described his further discoveries in the Upper Valdarno Basin. With the discovery of new elephant material, including several skulls, from Upper Valdarno Basin, Nesti (1825) was able to demonstrate that the Tuscan elephant represented indeed a new fossil species for which he created the name "Elephas" meridionalis, the first Early Pleistocene elephant species to be ever described (AzZAROLI, 1977a). Nesti's species is now recognised as an ancestral member of the mammoth lineage, and the Upper Valdarno sample provide a key to understanding its early evolution in Eurasia (LISTER et alii, 2005; LISTER, 2011; FERRETTI, 1999b).

Throughout the 1860 s and following years, the vertebrate collection was about to experience the most impor- 


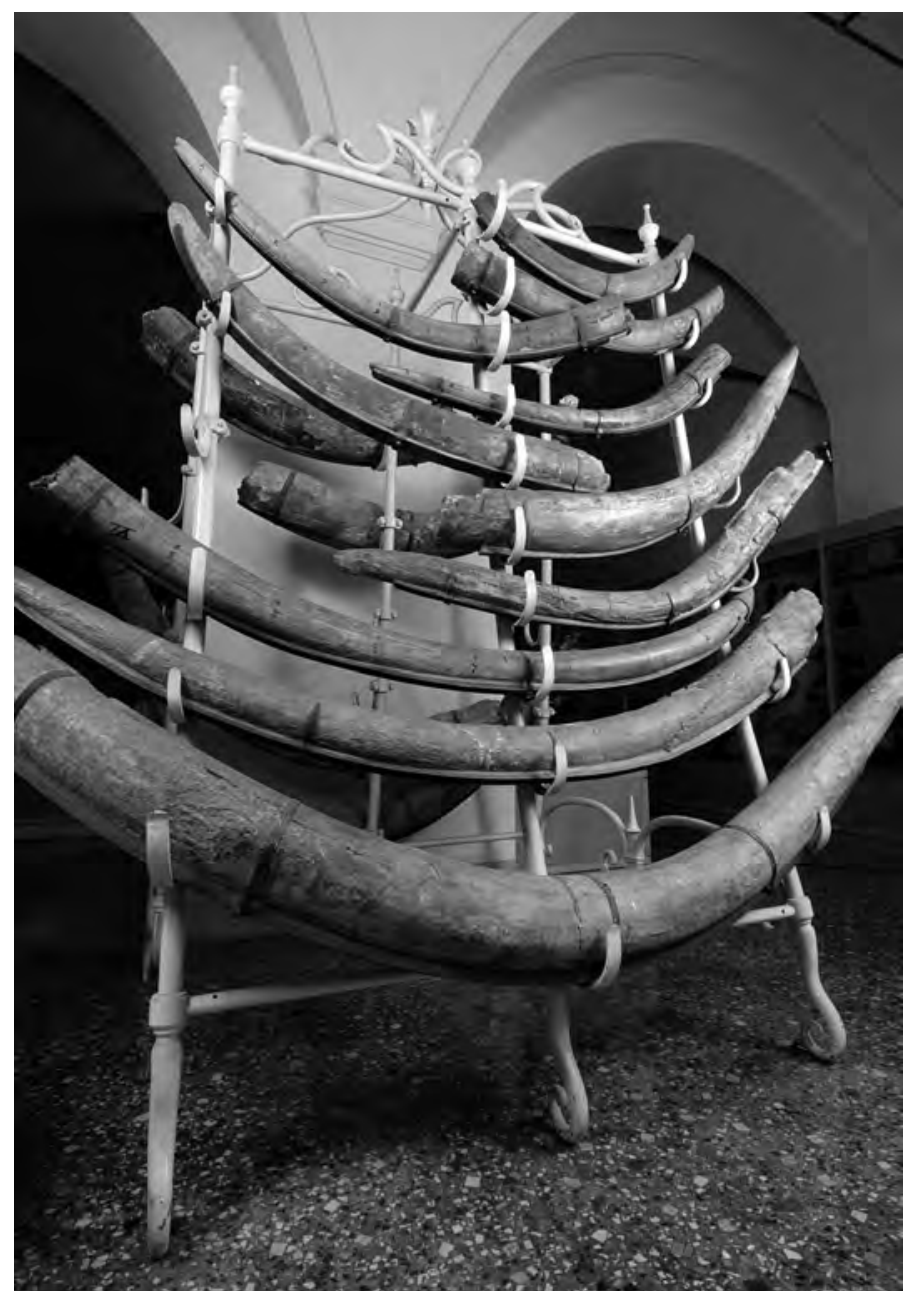

Fig. 1 - A remarkable "tusk-holder", a wrought iron frame for the display of proboscidean tusks, in the exhibit hall of the Museum of Natural History (Geology and Palaeontology Section) of the University of Florence.

tant growth since the times of Giovanni Targioni Tozzetti. The fate of the Upper Valdarno Basin collections and the Florence Palaeontological Museum became clearer in 1860 , with the nomination of Igino Cocchi as director of the Royal Institute of Advanced Studies, at a time when the most important growth of the collections was beginning in relation to the need to compile a geological map of Italy. Cocchi obtained unanimous approval of the establishment of an Italian palaeontological collection and central library in Florence (CORSI, 2003), and set out to expand the palaeontological collections with numerous acquisitions. Among several donors, is worth to mention the Florentine marquise Marianna Paulucci who donated her collections, among which significant specimens of Pleistocene mammals collected at Sammezzano in the Upper Valdarno, including skulls of the large sabretoothed cats Homotherium crenatidens and Megantereon cultridens (CIOPPI et alii, 2001; CiOPPI \& DoMINICI, 2010; Dominici \& CIOPPI, 2012). This phase was particularly linked to the arrival in Tuscany of the eminent Scottish palaeontologist Charles I. Forsyth Major. The latter has been a sort of pioneer in continental mammal stratigraphy, thanks to his interest for excavation work as a necessary starting point for an exact stratigraphic placement of the mammals from Upper Valdarno Basin (FoRSYTH

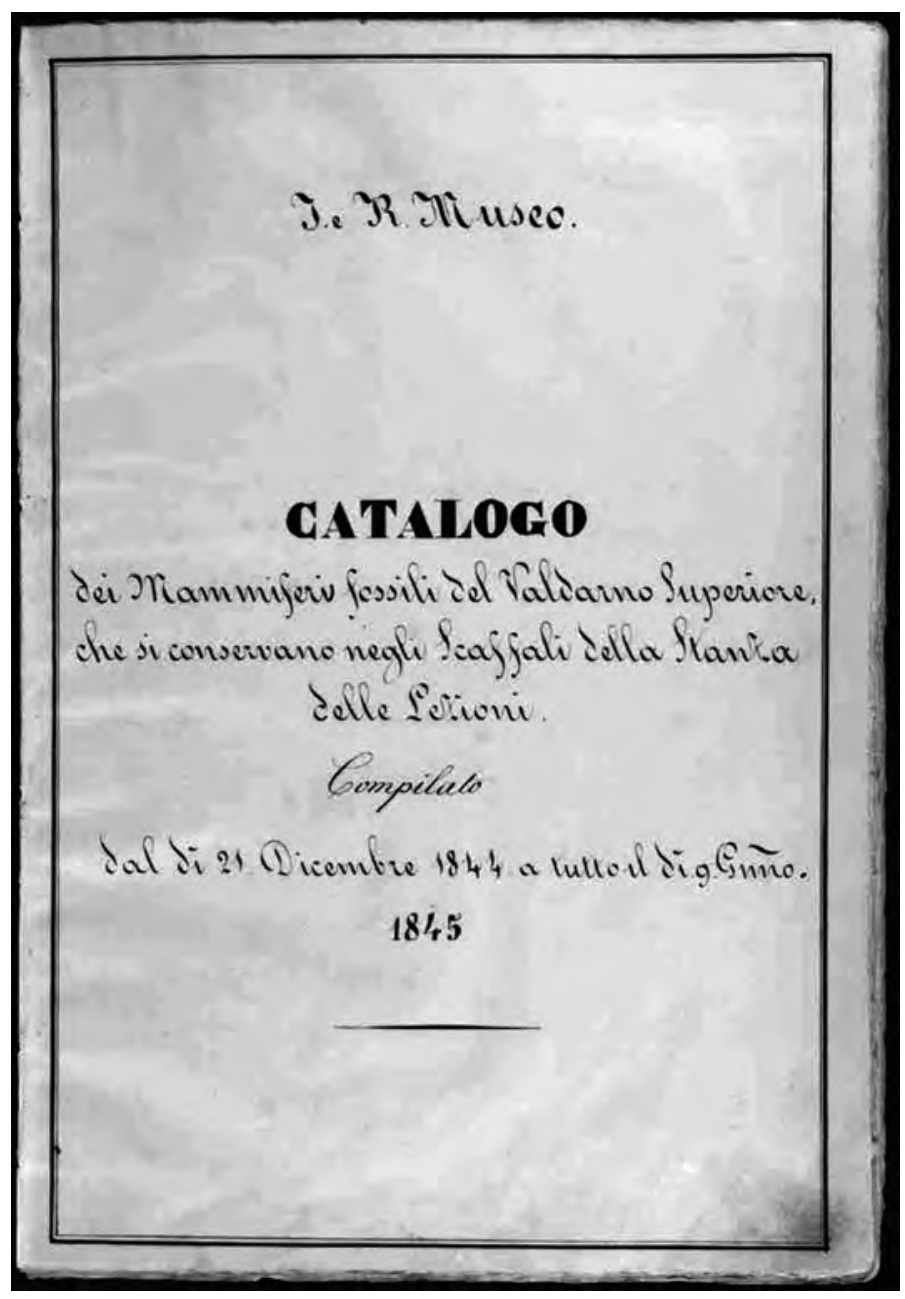

Fig. 2 - Frontespice of the Catalogue of fossil mammals from Upper Valdarno in the Florence Museum, compiled by F. Nesti in 1844-1845.

MAJOR, 1877). Whilst Forsyth Major was in Florence, he continuously and systematically was in search for new material from the main Tuscan sites, bringing to the museum hundreds and hundreds of specimens (RoOK \& AlBA, 2012).

In the time span across the end of $19^{\text {th }}$ and beginning of $20^{\text {th }}$ centuries, a number of palaeontologists contributed with abundant descriptive papers to extend our knowledge of the fossil mammals from Upper Valdarno Basin. Among these, reference works are those by Giuseppe Ristori, Alessandro Martelli and Domenico Del Campana. In this time increased also the interest in acquiring Upper Valdarno Basin collections by important European museums, like the Basel Naturhistorisches Museum in Switzerland (RooK, 2012).

In the mid of 1900s, a reappraisal of interest in Upper Valdarno Basin fossil mammals was due to the palaeontological work of Giovanni Merla, who arrived at the University of Florence to hold the Palaeontology chair in 1935. In the tradition of Earth Sciences at that time, palaeontology was a subject ancillary to Geology. Although the field of Geology was actually more congenial to Merla (in fact in 1948, when finally vacant, he took over the chair of Geology), he was fascinated by the investigation of the path of biological evolution as documented by fossils, especially 


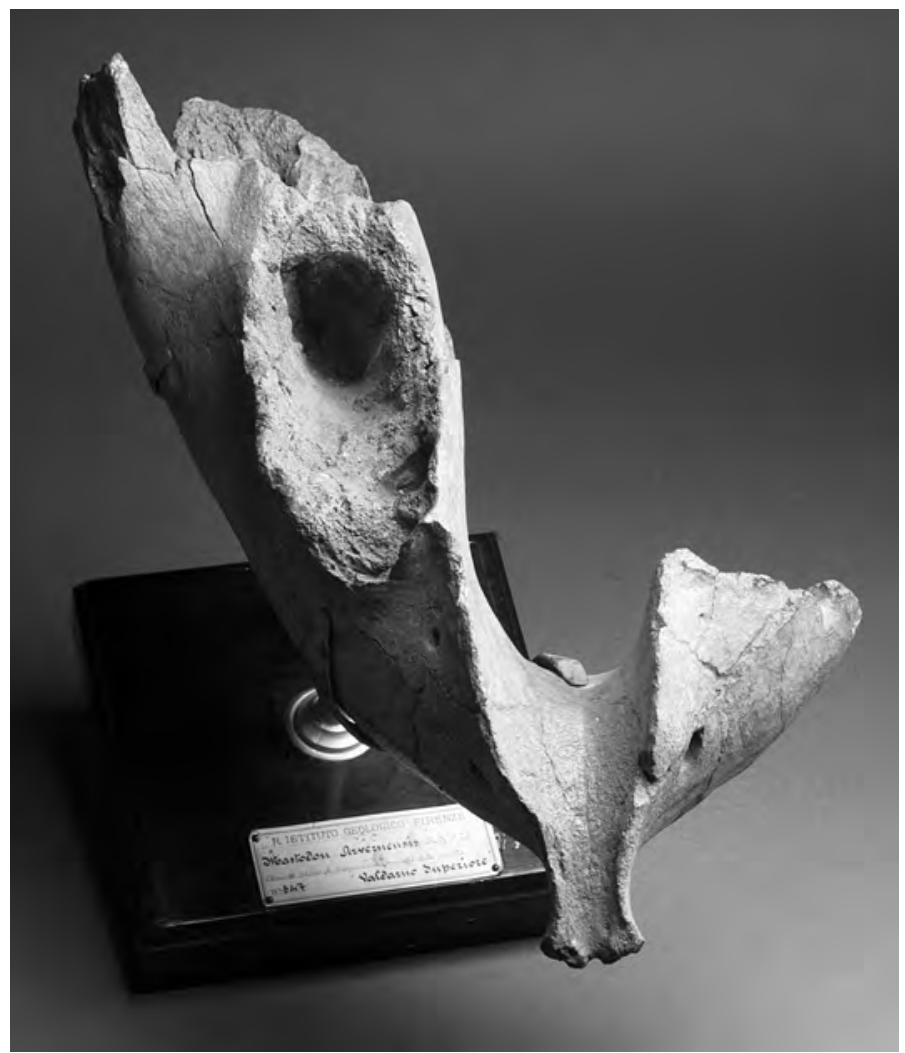

Fig. 3 - The Anancus arvernensis mandible illustrated by F. Nesti in 1808 in the first volume of the "Annali dell'Imperial Regio Museo di Firenze".

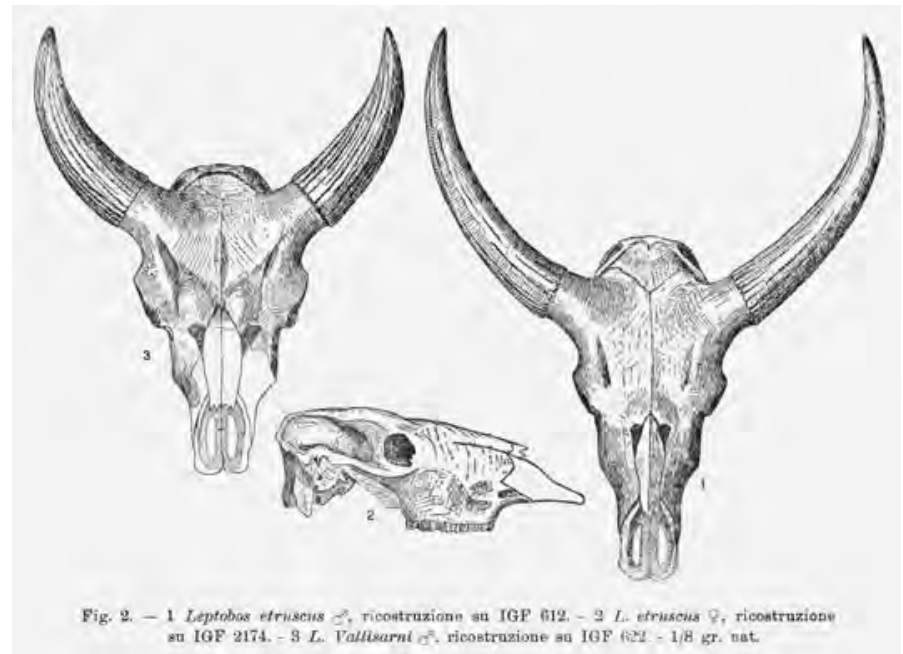

Fig. 4 - The illustration of the Upper Valdarno Basin Lebtobos species as in the 1949 original publication by Giovanni Merla (not in scale).

the faunas of Upper Valdarno Basin. Merla published in fact a reference monograph dedicated to the evolution of the genus Leptobos (MERLA, 1949), where he recognized a new species in the classical faunas of Upper Valdarno Basin (fig. 4), completed by a reconstruction of the evolutionary history of these bovids, with an analysis of primitive and derived characters and of their independent evolution in separate lineages (AzZAROLI, 1988).

During Merla's direction of the Institute in the immediate post-war period, Augusto Azzaroli began to develop palaeontological studies on Plio-Pleistocene vertebrate faunas, and it is thanks to him that vertebrate palaeontology became consolidated in Florence. Azzaroli held the Palaeontology chair in Florence (and the direction of the Museum of Geology and Palaeontology) from 1950 until his retirement in 1996. During this long time span the documentation and fossil collection from Upper Valdarno Basin increased considerably, from the first elephant skeleton Azzaroli recovered at Borro al Quercio (AzzAROLI, 1952), until the recent discoveries and recovery of important faunal associations, like those of Casa Frata in the early 1980s and Poggio Rosso in the 1990s (BoRSELLI et alii, 1980; NAPOLEONE et alii, 2001). The continuous interest in the study of Upper Valdarno Basin Plio-Pleistocene fossil mammals contributed to the ever-increasing knowledge of the biochronological subdivision of the Villafranchian (AzZAROLI et alii, 1982, 1988), and, in a broader sense, to the reconstruction of biotic and a-biotic events that charcterized the Plio-Pleistocene of central Italy (BERTINI, 2013; BONINI et alii, 2013; BROGI et alii, 2013; EsU \& GHINASSI, 2013; FIDOLINI \& ANDREETTA, 2013; Fidolini et alii, 2013; GHINASSI \& MAGI, 2004; GHINASSI et alii, 2004, 2005, 2013; RoOK \& ANGELONE, 2013).

\section{THE UPPER VALDARNO VERTEBRATE RECORD AND THE EUROPEAN MAMMAL BIOCHRONOLOGY}

To order fossils in geological time, vertebrate palaeontologists usually adopt biochronological time scales based on the evolutionary stages of the faunal assemblages and on the dispersal events that characterized the faunal sequences. The biochronological scale of the continental mammal assemblages of the Neogene and Quaternary in Europe has been developed since the 1960s-'70s thanks to the pioneering works of eminent palaeontologists such as Emile Heintz and Pierre Mein in France (Agustì \& RooK, 2011) and Augusto Azzaroli in Italy (RoOK \& MARTINEZNAVARro, 2010). Although its definition dates to the early 1900s (WILliams, 1901), the term biochronology was rarely used before the 1970s, when the use of radiometric dating techniques became widespread and there was the need to distinguish "radiochronology" and "biochronology" as different aspects of "geochronology". BERGGREN \& VAN COUVERING (1974) were the first to suggest an application of the term "biochron" for units of geological time based exclusively on palaeontological data, without reference to the lithostratigraphy or rock units that contain the fossils. All the chronological units developed and applied by vertebrate palaeontologists in continental sedimentation contexts are biochronological units, the socalled "Mammal Ages". The Villafranchian "Mammal Age" is a biochronological unit based on the European large mammal fauna and spans an interval including the Late Pliocene and Early Pleistocene (a period of ca. 2.5 million years, roughly between 3.5 and $1 \mathrm{Ma}$ ). The term Villafranchian was coined by PARETO (1865) as a continental stage referring to fluvial and lacustrine sediments with abundant mammalian fossils cropping out in the area of Villafranca d'Asti (Piedmont), although the fossil mammalian fauna of the Upper and Lower Valdarno Basins in Tuscany was also included in the original description. For years, the term was considered to refer to the most recent part of the continental Pliocene, and GIGNOUX (1916) proposed to correlate it with the Calabrian stage (defined on 
the basis of marine sediments), considering the latter the terminal part of the Pliocene. During the $18^{\text {th }}$ International Geological Congress in London in 1948, it was decided that the Calabrian represents the base of the Pleistocene, and therefore the Villafranchian was also believed to represent the continental Early Pleistocene. Since the 1960s, the work of Augusto Azzaroli and other famous European palaeontologists have demonstrated that the so-called "Villafranchian faunas" were not homogeneous and not even contemporaneous but represented a relatively long time period (AzzAROLI, 1962, 1970). The chronological subdivision of the Villafranchian was defined finally in the 1970s-1980s with the subdivision of the Villafranchian into successive "Faunal Units" (AzzARoLI, 1977b, 1983; GLIOZZI et alii, 1997; TORRE et alii, 2001) grouped respectively into Early, Middle and Late Villafranchian. In the standard Stratigraphic Scale of geological times (1), the Early Villafranchian now corresponds to the Late Pliocene (from $\sim 3.5$ to $\sim 2.6 \mathrm{Ma}$ ), the Middle Villafranchian to the first part of the Early Pleistocene (from $\sim 2.6$ to $\sim 2.0 \mathrm{Ma}$ ) and the Late Villafranchian to almost all the rest of the Early Pleistocene (from $\sim 2.0$ to $\sim 1.0 \mathrm{Ma}$ ). During this long interval, the composition of the mammal assemblages in Europe underwent profound changes. Even though the term "Villafranchian" has lost much of its original meaning (AzZAROLI, 1977b), it continues to be used for historical reasons and for nomenclatural stability; nevertheless, because the term has a stratigraphic meaning, it must always be specified to which part of it is being referred (Early, Middle or Late Villafranchian), or better to which of the Faunal Units is being referred (AzZAROLI, 1992; RoOK \& MARTÍNEZ-NAVARRO, 2010). A stratigraphic scheme summarising the Villafranchian subdivision and the occurrence of Faunal Units and Local Faunas within the Upper Valdarno Basin is provided in the conclusive chapter (fig. 26).

\section{A REVIEW OF SOME TAXA WITH PARTICULARLY RELEVANT RECORD IN THE UPPER VALDARNO}

\section{HERPETOFAUNA (MD)}

The presence of reptiles in the vertebrate assemblages of the Upper Valdarno Basin is known since 1836 when Cuvier wrote that a turtle shell from the surroundings of Montevarchi was "proche de Emys européenne". Since then, few other turtle remains, as well as some snake vertebrae, have been collected in several Early Pleistocene Upper Valdarno Basin localities known as Colombaiolo, Il Tasso, Le Mignaie and Montecarlo (San Giovanni Valdarno), Le Ville and L'Inferno (Terranuova Bracciolini), Poderaccio (Persignano) and Restone (also labelled as "Restoni", near Figline Valdarno). No amphibian or other reptile remains have been so far retrieved. The most comprehensive work dedicated to the herpetofauna of this area is still the paper by PORTIS (1890), where he described nine new extinct reptilian species, eight of

(1) Although still contested within the Quaternarist community (cfr. VAN COUVERING et alii, 2009; MCGOWRAN et alii, 2009), we follow here the recent formal IUGS recognition (June 2009) of Quaternary as a Period/System with the re-designation of the base of the Pleistocene Series/Epoch in the 2.59 Ma GSSP of the Gelasian Stage. which from Upper Valdarno Basin: three tortoises, Testudo globosa, T. oriens, T. seminota, three terrapins, Emys etrusca, E. major, E. latens, one marine turtle Pliochelis derelicta, and one colubrid snake, Coluber etruriae. Later taxonomic revisions of these species suggested that all of them, except Emys etrusca, should be considered nomina vana (sensu SANCHIZ, 1998) or simply junior subjective synonyms of other taxa.

\section{Tortoises}

The taxon most frequently mentioned in the literature is the tortoise Testudo globosa PoRTIs (1890) whose type specimen, IGF 960 (fig. 5 A-C) from the Le Ville (a locality were crop out sediments belonging to the uppermost part of the Montevarchi Synthem and that yielded fossil mammal attributable to the Tasso F.U.), is rather well preserved: the shell is not complete but the plastron is nearly perfect, with sutures and scute sulci clearly visible. As already noted by DELFINO \& CHESI (2008), recent revisions or comments on the status of $T$. globosa, gave different results: KoTSAKIS (1980) considered it as a valid species, whereas DELFINO \& BAILON (2000) indicated that T. globosa (as well as $T$. oriens and $T$. seminota) is most likely a synonym of $T$. hermanni, a synonymy explicitly supported also by LAPPARENT DE BROIN et alii (2006a, b, c). Worth noting is that PORTIS himself (1896), after a personal communication of G.A. Boulenger, considered T. globosa as a synonym of $T$. hermanni. Interestingly, Portis more than describing a new taxon, simply listed male morphological characters (without mentioning any sexual dimorphism in extant tortoises). Moreover, the pectoral/femoral ratio of IGF 960 is congruent with that of the western subspecies $T$. h. hermanni (and not with that of eastern $T$. $h$. boettgeri) indicating that this morphology was already established in peninsular Italy during the Early Pleistocene.

Even if the materials have not been revised with a modern approach, $T$. globosa is likely a junior subjective synonym of the living $T$. hermanni and not its forerunner as proposed by some authors (MŁYNARSKI, 1962; KOTSAKIS, 1980; HERVET, 2000). The type materials of T. seminota (fig. 5D; IGF 963) and T. oriens (fig. 5E; IGF 962) likely belong to $T$. hermanni as well, and therefore also the names $T$. oriens and $T$. seminota are junior subjective synonyms of $T$. hermanni. The hypoplastron referred to $T$. oriens is morphologically congruent with that of the corresponding element of $T$. hermanni (abdomino-femoral sulcus distinctly convex laterally and not reaching medially the hyo-xiphiplastral suture; hypoplastron involved in the posterior lobe of the plastron) whereas the hyoplastron on which $T$. seminota has been erected can be tentatively referred to $T$. hermanni even if the humeropectoral sulcus laterally reaches the axilla and not a point above it, as is generally the case in T. hermanni (compare $\mathrm{D}$ and $\mathrm{C}$ in fig. 6; even if unusual, the condition similar to that of $\mathrm{D}$ is sometimes present in extant $T$. $h$. hermanni as shown by the comparative specimen Naturhistorisches Museums Wien 13246:1).

\section{Terrapins}

The terrapin material has been recently revised by CHESI (2009) who also summarized the convoluted history of the name Emys etrusca PoRTIs (1890). In synthe- 


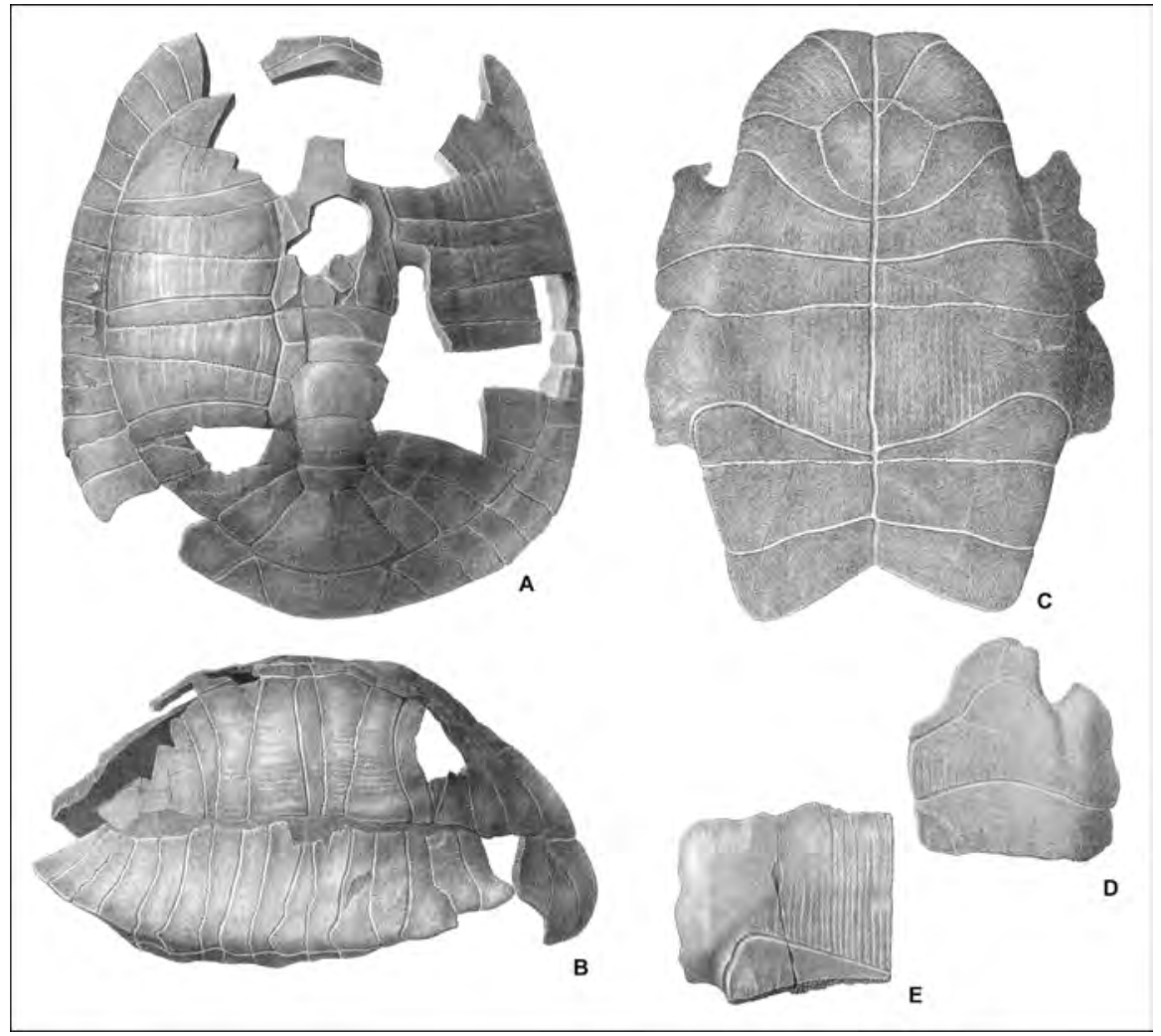

Fig. 5 - Type specimen, IGF 960, of Testudo globosa from Le Ville as figured by its author: A) carapace in dorsal view; B) carapace in left lateral view; $\mathrm{C}$ ) plastron in ventral view. Note that Portis indicated that, in order to improve the visibility of sulci and sutures, the carapace in dorsal view has been drawn more flattened than it is. The length of the shell is $26.3 \mathrm{~cm}$. Type specimen, IGF 963, Testudo seminota as figured by its author: D) left hyoplastron in ventral view. Type specimen, IGF 962, Testudo oriens as figured by its author: E) right hyoplastron in ventral view. D and E not to scale. All these three taxa erected by Portis can be considered as junior subjective synonyms of the extant Testudo hermanni and their type material referred to the latter species.

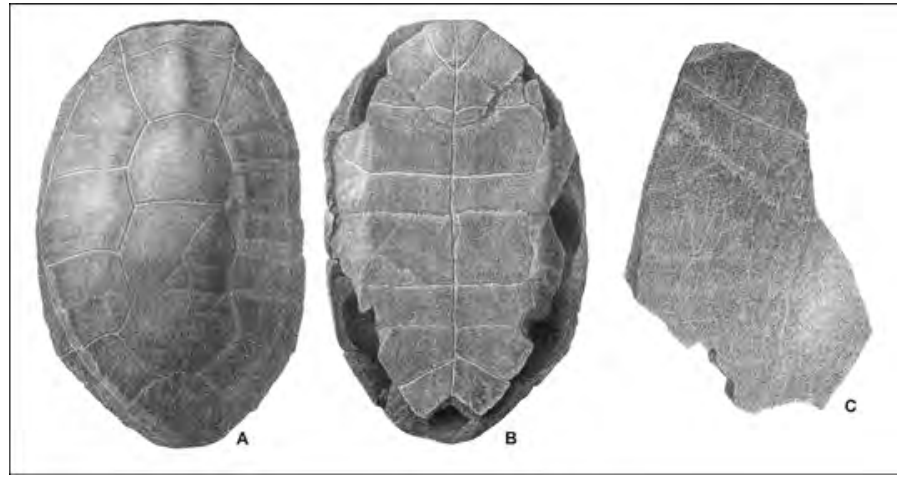

Fig. 6 - Type specimen, IGF 961, of Emys etrusca from Colombaiolo as figured by its author: A), B) dorsal and ventral view of the shell. According to CHESI (2009), this material can be referred to Mauremys etrusca. Total length of the shell is $16.3 \mathrm{~cm}$. Type specimen, IGF 965 , of Pliochelys derelicta from an undertermined locality (see text) as figured by its author: C) shell fragment in external view. The name Pliochelys derelicta is a nomen vanum and the material on which it was erected has to be referred to indeterminate Cheloniid turtles, Cheloniidae indet. The length of the fragment is $11.5 \mathrm{~cm}$.

sis, E. etrusca was described as a new taxon on the basis of a shell (IGF 961; fig. 6A,B) from Colombaiolo (a site located South of San Giovanni Valdarno, on the left of the Arno River, were sediments belonging to the mid-upper portion of the Montevarchi Synthem crop out) but just few years later Boulenger (in PORTIS, 1896) referred the same shell to the extant taxon Clemmys caspica (now genus Mauremys). BROIN (1977) accepted the generic identification by Boulenger, and proposed the new combination Mauremys etrusca, indicating, however, a possible synonymy with the extant $M$. leprosa. KotSAKIS (1980) referred IGF 961 to the extinct species Mauremys gaudryi but distinguished it at subspecific level, M. gaudryi etrusca. CHESI (2009) resurrected the specific status of the name etrusca providing evidence for the validity of the species Mauremys etrusca and studied its phylogenetic relationships with a cladistic approach.

Portis referred to Emys etrusca fossils coming from Colombaiolo and other localities. They are all referable to M. etrusca with the exception of a nuchal plate (IGF 969) from Montecarlo (a monastery two km South of San Giovanni Valdarno where sediments of the Pliocene Castelnuovo dei Sabbioni Synthem crop out). Its morphology is clearly congruent with that of Emys orbicularis, as already noted by KoTSAKIS (1980), and therefore should be better referred to Emys orbicularis. According to CHESI (2009), to the same taxon should be referred also the materials on which PoRTIs (1890) erected the new species Emys latens and E. major, taxa that are therefore junior subjective synonyms of Emys orbicularis.

\section{Soft shell turtles}

Portis described also some remains of a soft shell turtle from Colombaiolo that he cautiously referred to Trionyx sp. According to KoTSAKIs (1980), this material could be referred with doubt to the extinct species Trionyx pliopedemontanus (Trionyx cf. T. pliopedemontanus).

\section{Marine turtles}

As for the new genus and new species of marine turtle Pliochelys derelicta, erected on the basis of the single costal fragment IGF 965 (fig. 6C) that PoRTIs (1890) considered as coming from Colombaiolo, it is worth mentioning that KoTSAKIS (1980) after a personal communication by Augusto Azzaroli, indicated that the absence of marine sedi- 
ments in what we now call Upper Valdarno Basin renders quite unlikely that IGF 965 comes from this area, being more probable its origin in Val di Chiana Basin, where marine sediments crop out; Val di Chiana Basin (South of Arezzo) was formerly included in the "Upper Valdarno" by earlier students of the vertebrate palaeontology of Tuscany. Nevertheless, Pliochelys derelicta, that was formerly regarded as a synomym of Caretta caretta by Boulenger (in PORTIS, 1896) and KoTSAKIS (1980), is currently considered as a nomen dubium and its type material should be referred to undetermined cheloniids (CHESI, 2009).

\section{Snakes}

The snake vertebrae from Il Tasso (the locality that yielded the abundant mammal fauna, and that has been used to name the homonymous F.U. of the Late Villafranchian) represent the only evidence of small representative of the herpetofauna, being amphibians and other small reptiles not present in the fossil assemblage. PORTIS (1890) described the species Coluber etruriae on the basis of about 20 fragmentary vertebrae (now IGF 315, fig. 7, and IGF 316). DELFINO \& SzYNDLAR (2003) recently revised this material and concluded that even if it could possibly belong to the extant species Hierophis viridiflavus, it is too poorly preserved and uninformative to grant a proper identification. The name Coluber etruriae has been therefore considered a nomen dubium and the fossil material referred to "colubrines" indeterminate.

Summing up, the herpetofauna from the Upper Valdarno Basin is represented by extinct taxa like Mauremys etrusca and Trionyx cf. T. pliopedemontanus, as well as by extant taxa like Testudo hermanni and Emys orbicularis. Two of the taxa erected by Portis, Pliochelys derelicta and Coluber etruriae, are actually nomina dubia because they have been based by on materials that are non informative enough to diagnose a new taxon. The names of the tortoises Testudo oriens and T. seminota and of the terrapins Emys major and E. latens are respectively junior subjective synonyms of $T$. hermanni and E. orbicularis. Remarkably, the material of $P$. derelicta likely does not come from the Upper Valdarno Basin but possibly from Val di Chiana Basin.

The herpetofauna of Upper Valdarno Basin provides only very little biostratigraphic or biogeographic information, because all the taxa so far retrieved, with the exception of Mauremys etrusca, have long stratigraphic and wide geographic records.

\section{ORNITHOFAUNA (MP)}

The first generic report of fossil birds from the Upper Valdarno Basin is due to Cuvier, but these remains had

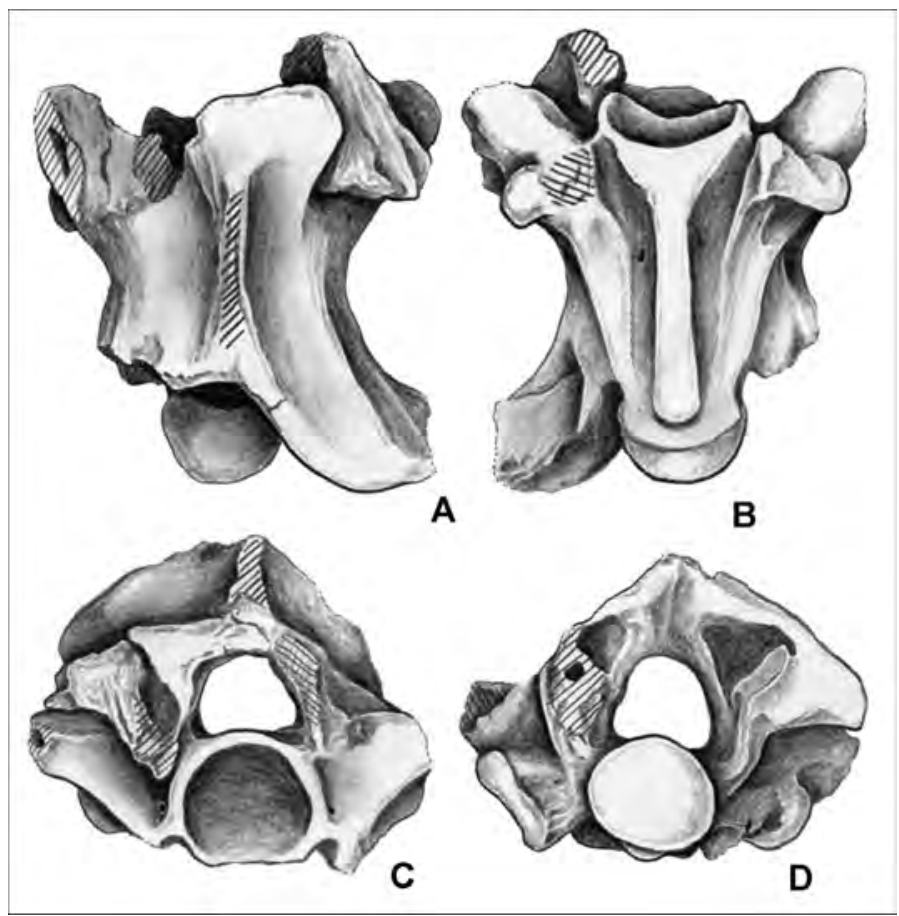

Fig. 7 - Syntype, IGF 316/1, of Coluber etruriae from Il Tasso: A-D) posterior trunk vertebra in dorsal, ventral, anterior and posterior views. According to Delfino \& Szyndlar (2003), Coluber etruriae Portis is a nomen vanum and its type material should be referred to indeterminate Colubrids, "colubrines" indet. The centrum length of this vertebra is $5.67 \mathrm{~mm}$ (Drawings by Z. Szyndlar, modified from DELFINO \& SZYNDLAR, 2003).

never been described in detail, and furthermore went successively lost (Portis, 1889, foot note on p. 3). Portis (1889) described six new extinct bird species, three of them from the Upper Valdarno Basin: two new species of Anatidae, Fuligula aretina and $F$. sepulta, and a species of Scolopacidae, Numenius pliocaenus. The taxonomic revisions of these species indicate that they should be considered as valid species (fig. 8).

\section{Diving Ducks}

Remains of these taxa are recorded only from the Late Pliocene locality of Montecarlo, and thus characterize the Castelnuovo dei Sabbioni Synthem.

Fuligula aretina (= Aythya aretina) was described on the basis of eight bones from Montecarlo: two cervical vertebrae (IGF 925 and IGF 929), one furcula (IGF 934),

Fig. 8 - Type specimens of the fossil birds from Upper Valdarno Basin as figured by PORTIS (1889). Aythya aretina, lectotype right tarsometatarsus IGF 930: A) dorsal view; B) plantar view. Aythya sepulta, lectotype left coracoid IGF 924: C) dorsal view; D) cranial view; E) lateral view. Corvus pliocaenus, holotype distal right ulna IGF 937: F) ventral view; G) dorsal view. The scale bars represent $1 \mathrm{~cm}$.
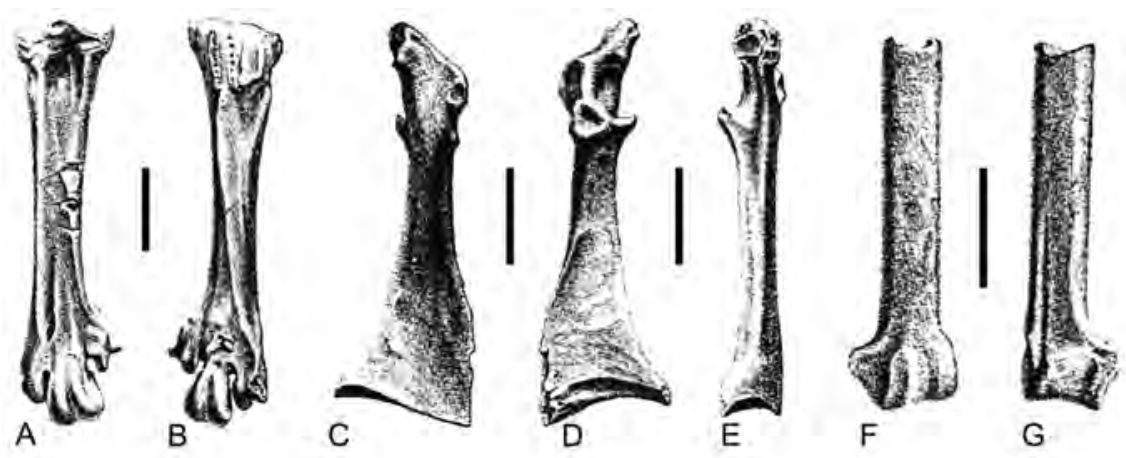
one fragmented left ulna (IGF 933), a proximal left carpometacarpus (IGF 935), two fragmented left femur (IGF 931 and IGF 936) and the lectotype right tarsometatarsus (IGF 930) selected by MLíkOvSKÝ (2002, p. 119) and one right tarsometatarsus from Le Strette (IGF 932).

Fuligula sepulta (= Aythya sepulta) was described on the basis of nine bones from Montecarlo: one cervical vertebra (IGF 922), one costa (IGF 927), one furcula (IGF 919), one left ulna (IGF 920), one right ulna (IGF 926), one left radius (IGF 921), one left carpometacarpus (IGF 928), one right carpometacarpus (IGF 923) and the lectotype left coracoids (IGF 924) selected by MLÍKOVSKÝ (2002, p. 119). After the original description of Portis, the two species have been moved in the genus Aythya by BRODKORB (1964), as Fuligula is the junior synonym of Aythya. Later on CHENEVAL $(1987,2000)$ moved them into the genus Anas without discussing this taxonomical change. These two taxa were again placed into the genus Aythya by Bocheńsky (1997) and TYRBERG (1998). The taxonomic validity of the two species was not questioned since the work of MLíkOVSKÝ (2002) where the author considered Aythya aretina and A. sepulta as a junior synonym of Anas platyrhynchos. This synonymysation was based only on the measurements reported in the original description (PORTIS, 1889), which were considered almost identical to those of Anas platyrhynchos by MLíKovskÝ (2002, p. 120), without analyzing the fossil bones. Later on Bedetti (2003) and BedetTi \& PAVia (2004), after the analysis of the type material and new material found at Pietrafitta mine (Umbria, Italy), confirmed the validity of the two species and their attribution to the genus Aythya. In particular $A$. aretina is the largest Ayhthya species ever described, even larger than Anas plathyrhynchos, while A. sepulta is smaller and can be separated from the similar-in-size species of the genus by some morphological characteristics, particularly in the lectotype coracoid.

\section{Corvids}

Numenius pliocaenus (= Corvus pliocaenus) was described on the basis of a distal end of a right ulna (IGF 937) from Il Tasso (PoRTIS, 1889). Later on Regalia (1902) correctly found the bone to belong to the genus Corvus. Thereafter the validity of the species has never been questioned, on the contrary it has been reinforced by MouRERCHAuviré (1975) with the description of the Pleistocene subspecies Corvus pliocaenus janossy. On the contrary MlíKovsKÝ (2002) placed $C$. pliocaenus, together with all the European middle-sized Corvidae species, into the living species Corvus corone. This extreme lumping was only justified by the fact that all those species fall in the same size categories with the modern Corvus corone (MLíkovskÝ, 2002, p. 233), in fact, as for the case of the two Aythya species, the author did not study the bones directly. BEDETTI (2003) restudied the type specimen of Corvus pliocaenus, comparing with all the European living and fossil species of Corvus and reach the conclusion that it should be considered as a valid species.

In conclusion, the ornithofauna of the Upper Valdarno Basin is only represented by three extinct taxa of different chronological position: Aythya aretina, A. sepulta (from the older Castenuovo dei Sabbioni Synthem) and Corvus pliocaenus (from the upper part of the Montevarchi Synthem), all of them described by PoRTIS (1889). Later taxonomic revisions of these species suggested that all of them should be considered valid species. From a biostratigraphic and biogeographic point of view, the two species of Diving Duck, Aythya aretina and A. sepulta, should be considered endemic of the Italian Pliocene, as they have been found only in the Upper Valdarno Basin and Pietrafitta mine. On the contrary, Corvus pliocaenus has longer stratigraphic and a wider geographic records and became extinct in the Middle Pleistocene.

\section{MAMmaLs}

An exhaustive overlook to the entire fossil mammal record of the Upper Valdarno Basin goes much further beyond the scope (and space availability) of the present contribution. We report in the following paragraphs an outline of the stratigraphic/evolutionary significance for just some of the large mammals that characterise the Upper Valdarno Basin fossil record. For an overview of the rodents and lagomorphs fossil record from the Upper Valdarno Basin we refer the reader to RooK \& ANGELONE (2013).

\section{Proboscidea (MPF)}

Five proboscidean species are described from the PlioPleistocene fluvio-lacustrine strata of the Upper Valdarno Basin. Different species or species associations characterize the three main depositional sequences of the Upper Valdarno Basin. From the Castelnuovo dei Sabbioni Synthem has been recorded Anancus arvernensis, while the occurrence of Zygolophodon borsoni is based on a single specimen of unsure provenance. Mammuthus meridionalis is recorded from the Montevarchi Synthem. Mammuthus primigenius, the woolly mammoth, and Palaeoloxodon antiquus are associated in the Torrente Ciuffenna Synthem. In the old (Granducal) collection of the Florence palaeontological museum there are some isolated remains of $P$. antiquus, including an incomplete skull (IGF 1067), whose provenance is indicated generically as "Valdarno Superiore" so that it is not possible to tell their exact stratigraphic level, though, based on present evidence, a co-occurrence with $M$. meridionalis seems unlikely. The Upper Valdarno Basin proboscideans were originally studied by NESTI $(1808,1825)$ and successively by FALCONER (1868), WeITHOFER (1890), Ricci (1901) and, in more recent times, by AzZAROLI $(1966,1977 a)$.

\section{Castelnuovo dei Sabbioni Synthem elephantoids}

From the Pliocene sediments of the Castelnuovo dei Sabbioni Synthem come abundant remains of the tetralophodont gomphothere Anancus arvernensis. In 1825 NESTI described and figured several skeletal remains belonging to one gomphothere individual (fig. 9) found in the vicinity of Montecarlo, a monastery two km South of San Giovanni Valdarno (Arezzo). Nesti referred the gomphothere fossils to "Mastodon" angustidens. Later, WeITHOFER (1890), who restudied the skull from Montecarlo in 1890 (IGF 319), correctly attributed the specimens to "Mastodon" arvernensis (= Anancus arvernesis). Other isolated remains of $A$. arvernensis were later recovered from several other localities in the Upper Valdarno Basin. Unfortunately, the exact levels of the Anancus remains from the Upper Valdarno Basin are not known. Though for most of the Anancus fossil the local geological 


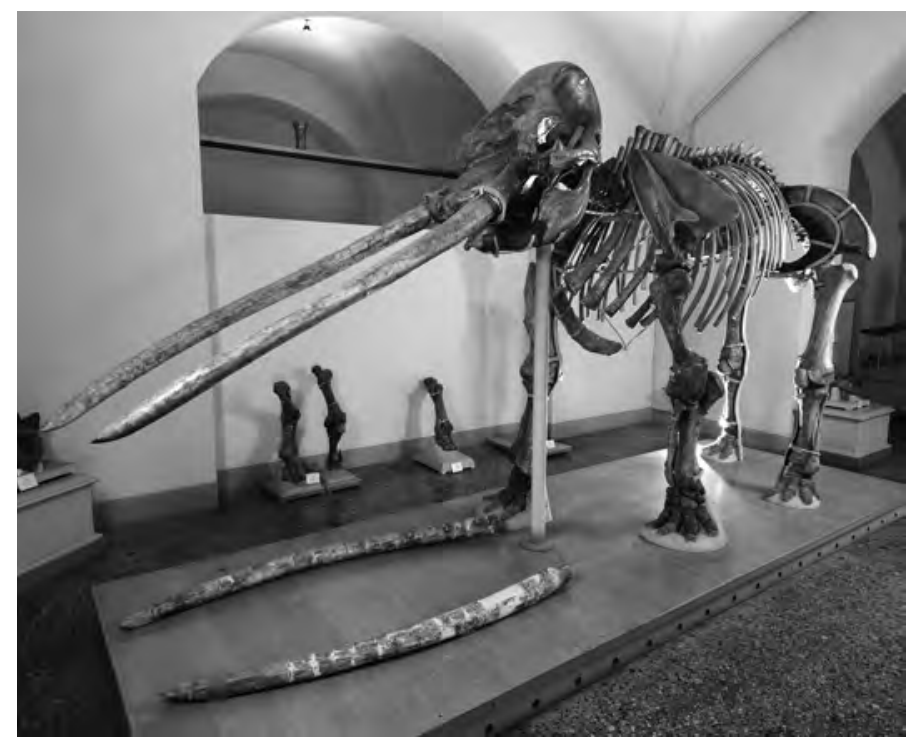

Fig. 9 - Composite skeleton of the proboscidean Anancus arvernensis from the surrounding of Montecarlo in Upper Valdarno Basin, recovered in the 1860's and described by F. Nesti.

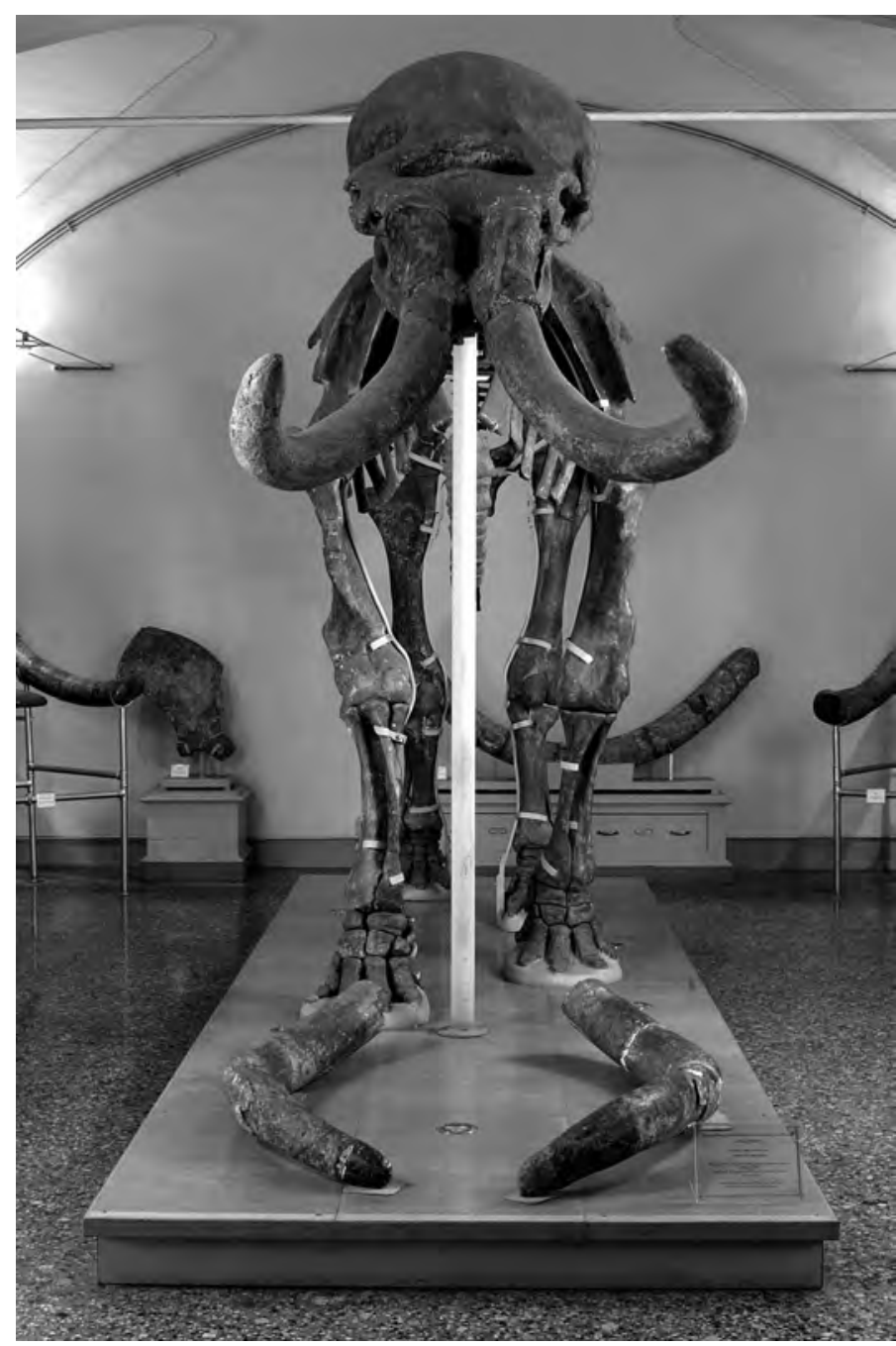

Fig. 10 - Mounted skeleton of an adult male of Mammuthus meridionalis recovered in 1952 by A. Azzaroli at Borro al Quercio, in the surrounding of San Giovanni Valdarno.

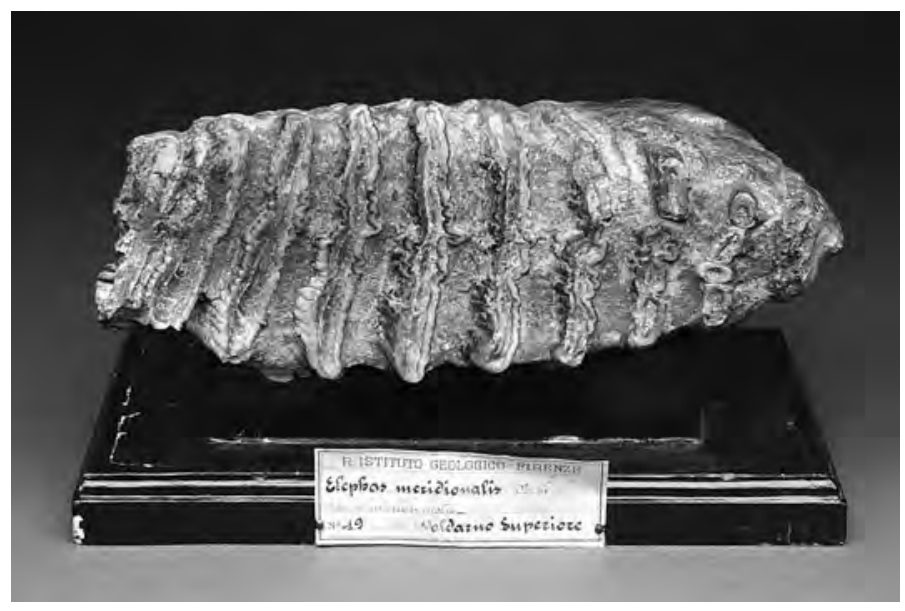

Fig. 11 - Occlusal surface of a Mammuthus meridionalis isolated molar from Upper Valdarno Basin housed among the historical collections of the Museum of Geology and Palaeontology of the University of Florence.

setting suggests they come from the Castelnuovo dei Sabbioni Synthem, in a few cases, as the remains from Sammezzano, a provenace from strata belonging to the Montevarchi Synthem (Olivola F.U.) cannot be excluded. A second elephantoid reported in the Castelnuovo dei Sabbioni sediments is the mammutid Zygolophodon borsoni. This is based on a single molar found in 1822 and now kept at the Museum of the Accademia del Poggio of Montevarchi, whose provenance is however uncertain, and might not even come from the Upper Valdarno Basin. Both taxa represent permanent-water dependent species, and in the case of mammutids, a forest dweller.

\section{Montevarchi Synthem elephants}

The strata of the second sedimentary cycle of the Upper Valdarno Basin are characterized by the disappearence of more primitive proboscideans and the first local occurrence of elephantids. NESTI (1825) described "Elephas" meridionalis (= Mammuthus meridionalis) from Upper Valdarno Basin based on three adult skulls: IGF 1054, choosen as lectotype by DePERET \& MAYET (1923), IGF 1049, and IGF 1067. The latter, however, was shown by WEITHOFER (1890) to belong to P. antiquus. More specimens were later described by FALCONER (1868), including two female skulls (IGF 1051 and IGF 1061), two juvenile skulls (IGF 23 and IGF 133) and an incomplete skeleton (IGF 1040). WEITHOFER (1890) in his study of the Upper Valdarno Basin proboscideans, established "E." lyrodon on the two female skulls, considering them to represent a different species from Nesti's one.

It was subsequently recognized, however, that " $E$." lyrodon is a synonym of "E." meridionalis. Successive findings considerably increased the $M$. meridionalis sample of Upper Valdarno Basin, that now includes four skeletons, several skulls, and hundreds of isolated teeth and bones (AzZAROLI, 1977a), most of which are housed in the Museum of Natural History (Palaeontology and Geology Section) of the University of Florence (figs. 10, 11) and in the Museum of the Accademia del Poggio of Montevarchi (Arezzo). On the basis of this material, M. meridionalis can be considered one of the best-known fossil elephants. It was a very large species, with huge and massive tusks, 


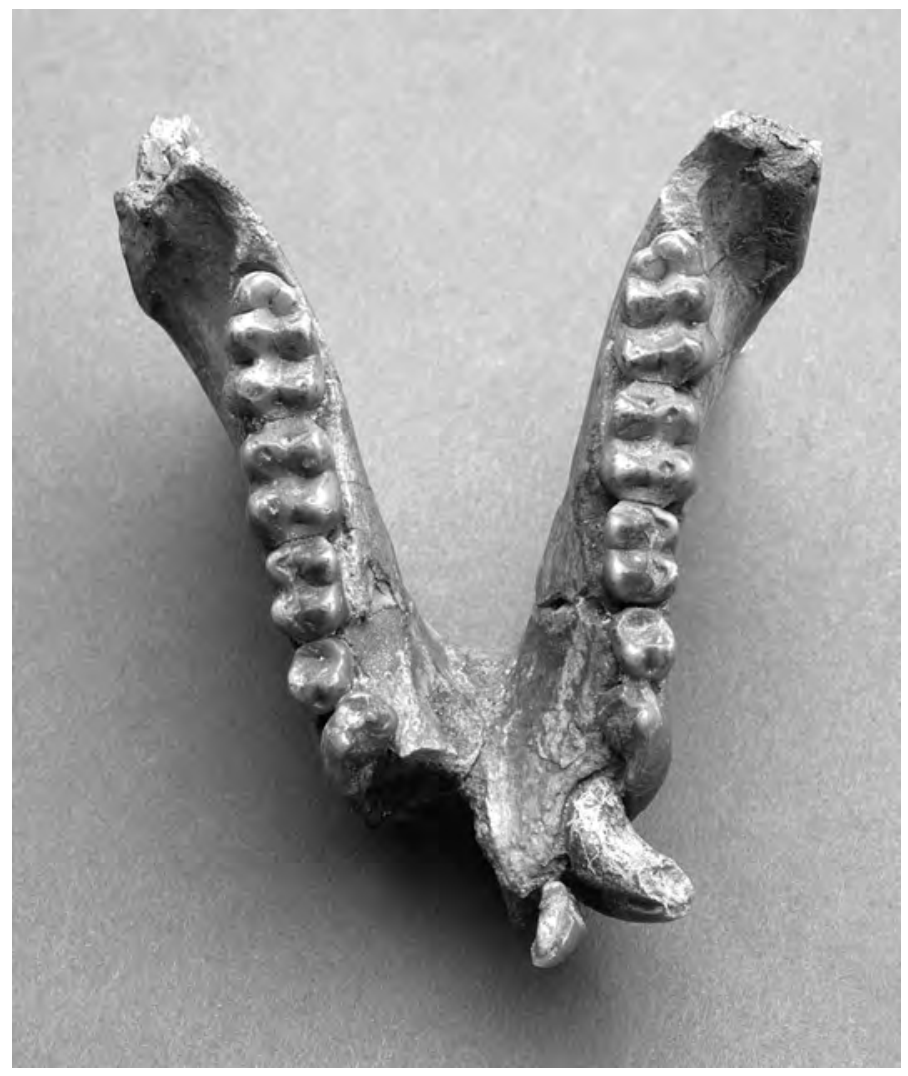

Fig. 12 - Mandible of Macaca sylvanus florentina. On this specimen I. Cocchi established the new species "Inus florentinus" in 1865.

typically spiralled. An ecomorphologic analysis, suggested that $M$. meridionalis was a woodland inhabitant with feeding habits similar to modern Loxodonta africana (FERRETTI \& CROITOR, 2001). Though nearly all authors agree in considering $M$. meridionalis related to the wolly mammoth, some authors prefer to include this species in a distinct genus, Archidiskodon, created by POHLIG in 1885 just to accomodate Nesti's species. Recent morphological and phylogenetic analyses, however, indicate that $M$. meridionalis form a monophyletic group with the other Eurasian and North American mammoth species, as $M$. trogontherii and $M$. primigenius, supporting its inclusion in the genus Mammuthus (LISTER et alii, 2005; FERRETTI \& DEBRUYNE, 2010).

\section{The Torrente Ciuffenna Synthem elephants}

The more recent deposits of the Upper Valdarno Basin, cropping out around Arezzo, yielded abundant remains of the woolly mammoth and of $P$. antiquus, the latter seemingly associated with human artefacts (MAzzA et alii, 2006). These two species were widely distributed across Eurasia during the Late Pleistocene, though they are considered to differ markedly in their climatic and ecological tollerance, with the woolly mammoth being more adapted to cold and arid conditions. It cannot be excluded that their association in the Torrente Ciuffenna Synthem is the result of time averaging.

\section{Primates (LR)}

With the exception of Macaca majori from Sardinia, currently considered a distinct, endemic species (DELSON et alii, 2000; Rook \& O’HiggINs, 2005), Plio-Pleistocene macaques from Europe are customarily referred to several subspecies of the Barbary macaque, Macaca sylvanus. The type of Macaca sylvana florentina from Upper Valdarno Basin (COCCHI, 1872), is represented by a quite complete mandible from Le Forre (fig. 12), and the fossil record of this Basin includes a number of other remains (especially mandibles and lower teeth and few postcranial bones), from a suite of localities within the Montevarchi Synthem, all attributable to the Tasso F.U.: Il Tasso, Le Strette, Le Ville, Le Mignaie, Case Inferno, Terranuova (RooK, 2009).

The classification of fossil European macaques as temporal-geographic subspecies of $M$. sylvanus, following the proposal by SzALAY \& DELSON (1979), is currently followed by most investigators (JABLONSKI, 2002; ALBA et alii, 2008). However, Szalay \& Delson (1979, p. 359) already noted that these fossil macaques are not "clearly or significantly distinguishable from the living northwest African M. sylvanus", so that "pending a more complete revision, all are referred to subspecies of this taxon, defined in part by biochronology". Unfortunately however, these authors failed to provide an operational diagnosis of the several subspecies, so that the lack of adequate diagnostic morphologic criteria has complicated the subspecific attribution of several samples of fossil European macaques (Rook et alii, 2001; AlBA et alii, 2011).

\section{Carnivora (LR)}

Several Plio-Pleistocene carnivores from Upper Valdarno Basin are type specimens of the best known species in the Quaternary palaeontological literature. Some of the most important carnivore specimens were collected in the late $19^{\text {th }}$ century, and pivotal papers on fossil carnivores - still reference works - are those by FORSYTH MAJOR (1877, 1890), FABRINi (1890) and Del CAMPANA (1913, 1914, 1915-16).

\section{Ursidae}

Among the mammals of the faunal assemblage from Castelnuovo dei Sabbioni Synthem is the small bear Ursus minimus. The skeleton of the small ursid Ursus minimus, similar in appearance to the Tibetan black bear of southern Asia, deriving from lignite strata at Gaville, was recovered and studied by RISTORI (1897) and later revised by BERZI (1966).

A relatively common carnivore in the Upper Valdarno fossiliferous sites within the Montevarchi Synthem is the typical Late Villafranchian bear Ursus etruscus, one of the fossil taxa from Upper Valdarno Basin first described and illustrated by CUVIER (1812, 1821-24; fig. 13). A recent revision of this species (MAZZA \& RUSTIONI, 1992) revealed a progressive change in several craniodental traits (as the muzzle elongation, reduction of anterior premolars, simplification of the occlusal surfaces of the back teeth).

\section{Canidae}

Among the Upper Valdarno Basin carnivores, special mention must be given to the fossil dogs. Three species are typical of the Late Villafranchian and were 


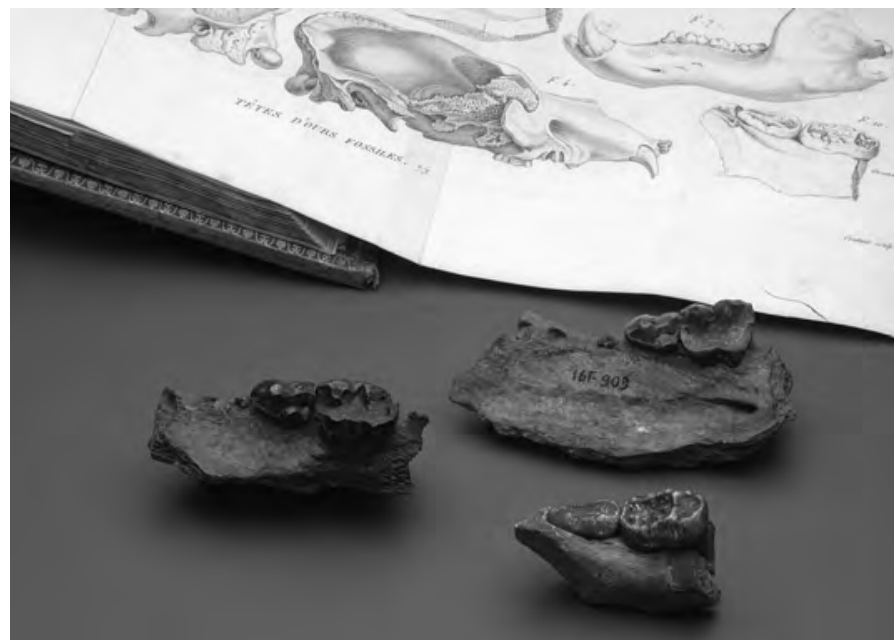

Fig. 13 - Some of the of Ursus etruscus specimens kept in the Florence Museum, studied (and figured) by the French palaeontologist G. Cuvier in his "Rechérces sur les ossemènts fossils" in the early 1800s.

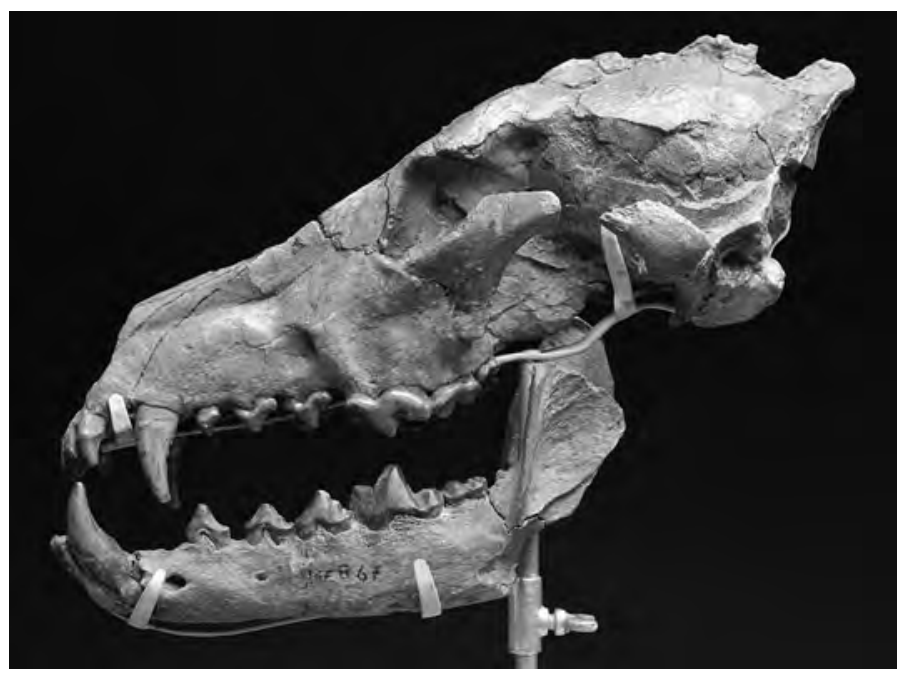

Fig. 14 - One of the Upper Valdarno Basin fossil dogs: Canis arnensis. The specimen was first studied by Charles I. Forsyth Major in the 1870s, and then revised by D. Del Campana in the 1910s and by D. Torre in the 1960s.

named by early researchers based on material from the Upper Valdarno Basin collections. FORSYTH MAJOR (1877) erected two still valid species, Canis etruscus (an early wolf, whose type specimen is kept in the Museo dell'Accademia del Poggio in Montevarchi) and Canis falconeri (a primitive wild-dog recently re-classified as Lycaon falconeri; MARTínez-NAVARRO \& ROOK, 2003), whose type specimen is the fragmentary palate IGF 883 from an unrecorded locality in the Upper Valdarno Basin. Del CAMPANA (1913) published another pivotal paper on fossil dogs from Tuscany. Del Campana clarified and expanded some of Forsyth Major's descriptions and recognised, within the Upper Valdarno Basin sample, a third, smaller jackal-sized species he named, in honour of the Arno River, Canis arnensis (fig. 14). The appearance of large dogs in the Late Villafranchian fossil record was used by AzzARoLI (1977b) to define one of the events that characterised the beginning

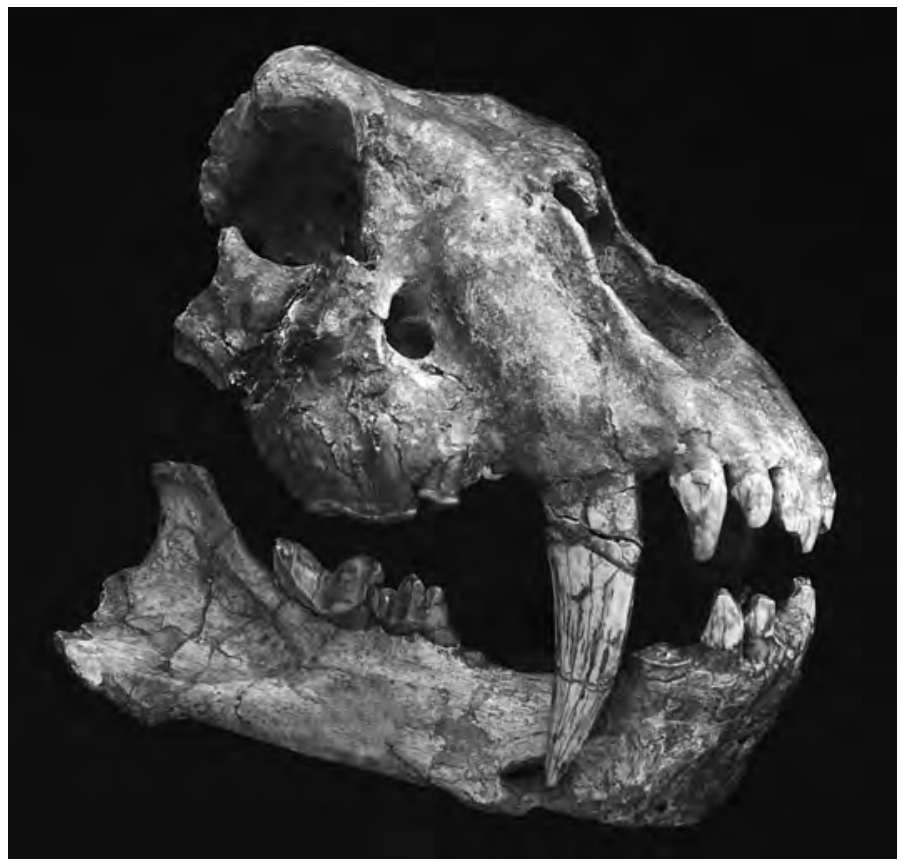

Fig. 15 - A partial skull of the sabre-toothed cat Homotherium crenatides. The Upper Valdarno Basin fossil record includes two different sabre-toothed species, H. crenatidens and Megantereon cultridens.

of the Late Villafranchian, "the wolf-event" (Rook \& TORRE, 1996).

\section{Felidae}

An important sample among felidae is represented in the Upper Valdarno Basin collections by two different saber-toothed species, Megantereon cultridens and Homotherium crenatidens. The first species was described as Ursus cultridens in an early paper by CUVIER (1821-24) on the basis of an upper canine fragment and an upper canine cast both from the Upper Valdarno Basin. The nomenclatural history of this species has been quite complicated, and a clarification of proposed genera and species was published in late 1970s. Re-defining the species Megantereon cultridens (CUVIER 1821-24), FICCARELLI (1979) proposed as lectotype of the species an upper right canine (IGF 816). The second sabre-toothed species belongs to the genus Homotherium, erected by FABRINI (1890) based on material from the Upper Valdarno Basin (the syntypes being two upper canines IGF 817 and IGF 820). Homotherium is larger than Megantereon and has relatively "shorter", more robust upper canines. The Homotherium upper canines (as well as incisors, premolars and molars) are characterised by typically crenulated cutting edges (fig. 15).

The Late Villafranchian carnivore record includes more big cats. Panthera toscana (nowadays commonly considered a junior synonym of Panthera gombaszoegensis) is an European jaguar, which dispersed into Eurasia from Africa around $2 \mathrm{Ma}$ and survived in our continent until the end of the Early Pleistocene; the specimens from Tuscany have been described as Leopardus arvernensis in some reference papers, e.g. those by FABRINI (1890) and Del CAMPANa (1915-16). SCHAUB (1949) had the opportunity to study some of the Florence specimens and named 


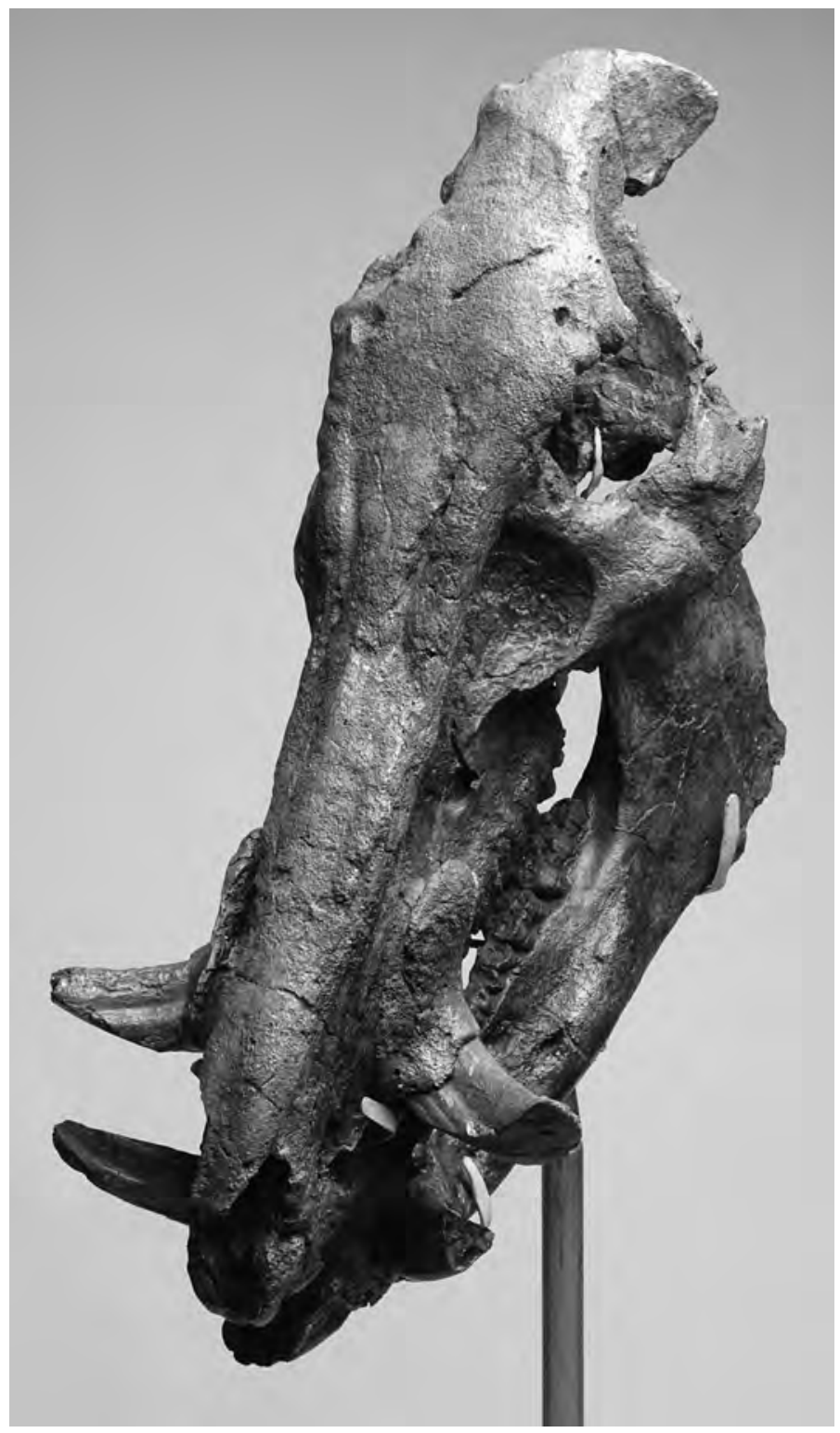

Fig. 16 - Type specimen of the Upper Valdarno Basin boar, Sus strozzii.

the specimens from Tuscany "Felis toscana", designating as holotype the right mandible IGF 851 from "Santa Maria" near "Il Tasso". Acinonyx pardinensis is a large fossil cheetah, well known in Eurasia during Villafranchian times. The species is present at Olivola (in Val di Magra, North-western Tuscany), and Casa Frata in the Upper Valdarno Basin.

\section{Hyaenidae}

The occurrence of Pliohyaena perrieri from an unrecorded locality of the Upper Valdarno Basin was one of the elements suggesting for long lime the occurrence of Middle Villafranchian-bearing horizons in the Basin. The typical large hyaenidae of the Late Villafranchian is Pachycrocuta brevirostris, particularly abundant is the Late Villafranchian Upper Valdarno Basin record. Palaeontologists have held discordant opinions on the taxonomic positions of Plio-Pleistocene large hyaenas:
Hyaena brevirostris Aymard (= Hyaena robusta Weithofer) and Hyaena perrieri Croizet \& Jobert, both widespread in the Villafranchian and Middle Pleistocene of Europe. KRETZOI (1938) described two new genera, ascribing the species brevirostris to Pachycrocuta and the species perrieri to Pliocrocuta. Pachycrocuta brevirostris is the largest hyaena that ever existed, a hyper-scavenger with a body weight that could easily reach $120 \mathrm{~kg}$. It has been one of the principal agents responsible for the bone accumulations across the entire Eurasian continent at that time.

Another Late Villafranchian hyaenidae species occurring - although rare - in the Upper Valdarno Basin record is the hunting hyaena Chasmaporthetes lunensis. The genus Chasmaporthetes includes a number of fossil pliopleistocene species from North America, Africa and Eurasia that are characterised by slender skeletal structure, cursorial adaptations and dentition relatively less robust than in bone-cracking hyaenas, a set of features suggesting Chasmaporthetes may have been a more active predator than a scavenger (KURTÉN \& WERDELIN, 1988; FERRETTI, 1999a). Chasmaporthetes is known in Italy with two species. C. lunensis, originally described by DEL CAMPANA (1914) with the old generic name Euryboas, is documented from the type locality of Olivola (Val di Magra) and is known also from the locality "Inferno" in Upper Valdarno Basin. The second species know in the fossil record of Italy is Chasmaporthetes melei (Rook et alii, 2004) an endemic species of the Plio-Pleistocene of Sardinia, quite an exception for an insular ecosystem (LYRAS et alii, 2010).

\section{Artiodactyla}

\section{Suidae (GG)}

The only suid species occurring within the Upper Valdarno Basin fossil record is Sus strozzii (fig. 16). FORSYTH MAJOR in 1881 reports its occurrence in the paper "Studi sugli avanzi Pliocenici del genere Sus" although for a complete description of the species and an exhaustive discussion of its taxonomic status we have to wait until the work of AzzAROLI (1953a). The species has been recently revised in Gallai (2006). Sus strozzii is a large-sized species, characterised by elongated nasals (sometime enflated in male individuals) and by pneumatised zygomatic arches. Its molars are simple structured with mainly cutting function in occlusion, and the canine margin is of "verrucose" type. The mandible is characterised by medial pachyostosis along the horizontal ramus and short sympisean region. The species morphology shows affinities with the group Sus verrucosus-Sus celebensis. Sus strozzii derives from the European Pliocene species Sus arvernensis (AzZAROLI, 1953a), and is a species widely distributed in Europe from Early to Late Villafranchian. A recent analysis of the Italian fossil record of this species has shown that Sus strozzii is characterised by a low intraspecific variability with no significant difference among the fossil specimens documented from several Italian localities (GALLAI, 2006).

\section{Cervidae (RC)}

Deer of Eucladoceros are easily recognizable by their peculiar comb-like antlers. This important character 
makes the essential part of the genus definition, while the significance of dental and cranial characters remain disregarded.

\section{Eucladoceros dicranios (NESTI, 1841).}

E. dicranios is the type species of the genus. The species was for the first time indicated in the report of F. Nesti made in 1841 at a scientific meeting and summarized by P. Savi \& A. Sismonda. Azzaroli \& MAzzA (1992), matching Nesti's report and the Catalogue of fossil vertebrate collections from Florence compiled soon after the report was made (fig. 2; CiOPPI \& DoMINICI, 2010), discovered that the original description of the species was based on the antlered skull IGF 270 (fig. 17) and explicitly named this specimen as holotype (AzzAROLI \& MAZzA, 1992: 47). Although E. dicranios is the most advanced species of the genus, it still maintains the comb-like structure of antler. The antler construction basically is the same as in E. ctenoides, with a first tine situated at a certain distance from the burr, an accessory subulate tine situated in the area of first ramification some-what medially (it is directed upright on the antlered skull), and three crown tones inserted on the anterior side of the antler beam. The antler beam and tines (with exception of the accessory subulate tine) are pronouncedly compressed from the sides. The first and crown tines are bifurcated and trifurcated, therefore the right antler has 14 points, while the left one has 12 points (DE Vos et alii, 1995). The antler beams are curved sidewards therefore the antlers give a special "brushy" impression. This subjective optical illusion caused the incorrect description of antler shape as "brush-like" reported, for instance, by GEIST (1998), while the taxonomically significant comb pattern of antler construction remained overlooked. The skull of E. dicranios is characterized by a set of traits correlated to an increased antler weight: the angle between facial and neural parts of the skull is stronger pronounced, the neurocranium behind pedicles is comparatively shorter, lower and broader. Pedicles are strong and robust; however, their position of cranium is the same as in E. ctenoides.

$E$. dicranios is a less common species in Upper Valdarno Basin, but also in the palaeontological record of Europe. However the area of distribution of E. dicranios is very vast comprising Western Eurasia from the Azov Sea planes in the East and England in the West. Well preserved antlers of $E$. dicranios are described from Bacton, Norfolk (England) as Eucladoceros sedgwickii and from Liventzovka (Azov Area, Russia) as Eucladoceros cf. dicranios. The finds from Italy, England and Russia display some minor morphological differences one from another (AzZARoli \& MAzZA, 1992; DE Vos et alii, 1995), however it is impossible to estimate the significance of those differences since we have in our disposal only one complete specimen from each locality.

\section{Eucladoceros ctenoides (NESTI, 1841).}

The species was first described by F. Nesti in 1841 from Upper Valdarno Basin. The holotype IGF 377 is a right almost complete antler with a small portion of pedicle attached (fig. 18). This is a less evolved species characterized by simple metameric comb-like antlers with four of five tines (the accessory rudimental tine is not counted). The first tine is situated at a certain distance from the burr, unbranched and cylinder-shaped. A small

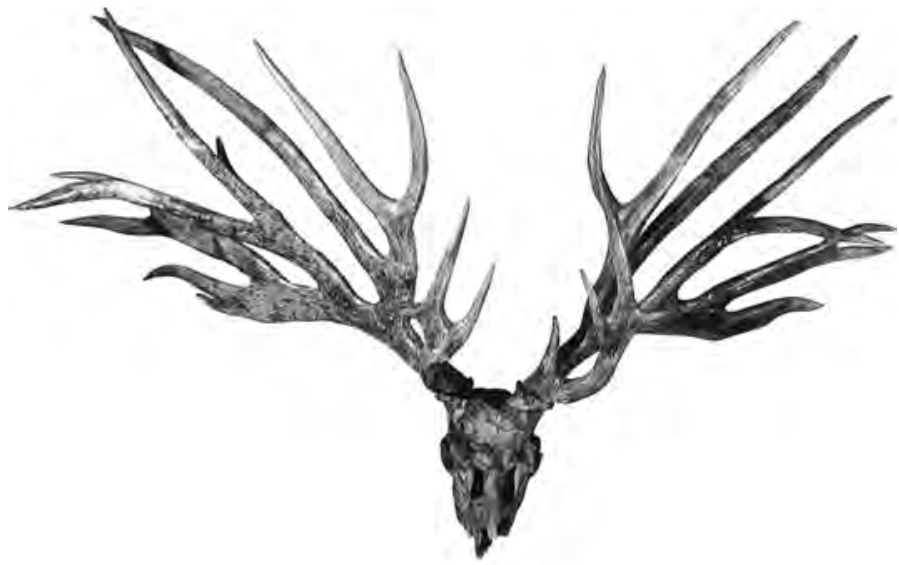

Fig. 17 - The magnificent Eucladoceros dicranios type skull as figured in Azzaroli \& MAZza (1992).

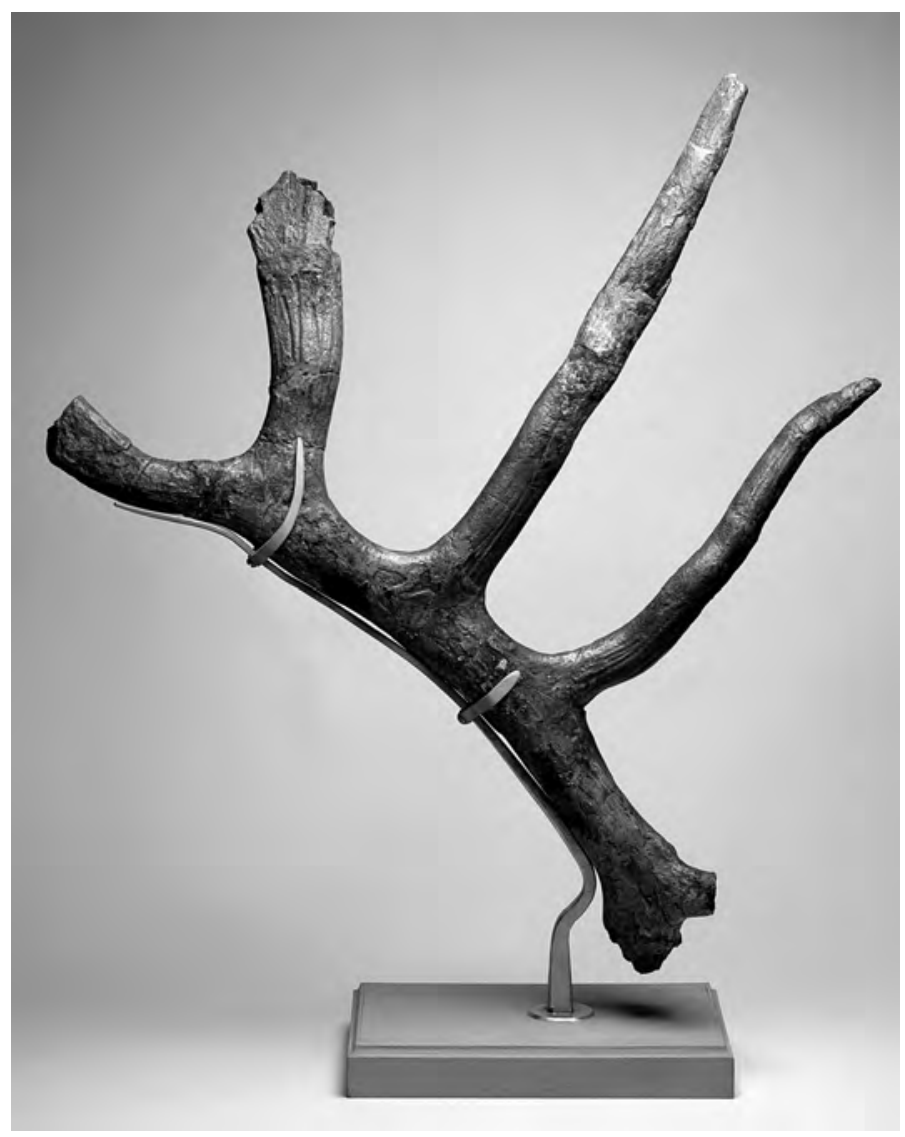

Fig. 18 - Partial antler of Eucladoceros ctenoides, type specimen of the species.

accessory tine is situated in the area of first ramification on the antero-medial side of the beam. This accessory tine is often preserved as a knob-like vestige. The antler beam is slightly compressed from the sides between the first and the second tine, and became strongly compressed from the sides above the second tine. The crown tines are situated on the anterior side of the beam and form a right angle with the beam. The crown tines normally are compressed from the sides at a variable degree. The antler crown consists of three or four crown tines, 
which normally are not branched and show a small dichotomic ramification in their distal portion only in some well-grown hypertrophic specimens. The dichotomic branching of crown tines is a noteworthy character of E. ctenoides that is disregarded. Azzaroli \& MAzzA (1992) observed that the dichotomous branching is clearly recognizable on the fourth tine of the holotype specimen, even if that tine is not complete. Apparently, the apical fifth tine also was dichotomously branched. A similar spontaneous dichotomy of crown tine is observed in the antlered skulls of Eucladoceros from Senèze stored in Paris and Basel (HEINTZ, 1970), and some antlers from Olivola (AzZARoli, 1947). Azzaroli \& MAzZA (1992) proposed a new subspecies E. dicranios olivolanus for the Eucladoceros form from Olivola (Italy), which, according to their opinion, represents a mixture of characters of E. ctenoides and E. dicranios and was regarded as a forerunner of those two species. The holotype of E. dicranios olivolanus is a distal portion of antler IGF 1402 with three crown antlers. In his earlier paper, AzzAROLI (1947) described this specimen as Cervus (Euctenoceros) ctenoides. Two crown antlers have their distal parts bifurcated reminding to a certain extent $E$. dicranios. The first tine in Eucladoceros from Olivola is cylinder-shaped and unbranched as in E. ctenoides. Since the occasional incipient bifurcation in crown antlers is characteristic of E. ctenoides, this incipient crown tine bifurcation, apparently, should be regarded as a hypertrophy, but not a transitional evolutionary stage between E. ctenoides and $E$. dicranios. Therefore, E. dicranios olivolanus is a junior synonym of E. ctenoides, or, at list, should be kept as the subspecies E. ctenoides olivolanus (CROITOR \& POPESCU, 2011). Unlike the antler hypermorphy in E. dicranios, the antler hypertrophy in E. ctenoides ctenoides is stronger expressed in posterior crown tines.

The area of distribution of E. ctenoides is rather limited and includes only Western and Mediterranean Europe (CROITOR \& BONIFAY, 2001). This species is rather polymorphic being represented by several local and chronological forms distinguished mainly by morphological details of antlers (length, shape and direction of crown tines, their position on beam) (AzzAROLI \& MazzA, 1992; De Vos et alii, 1995). From the beginning, each local variant of $E$. ctenoides was labeled by a specific name that created a taxonomical confusion (DE Vos et alii, 1995). Today, many authors place the numerous species names (senezensis, darestei, falconeri, tegulensis, and tetraceros) in the list of synonymy of E. ctenoides (DE Vos et alii, 1995; CROITOR \& BONIFAY, 2001; VALLI \& Palombo, 2005). Perhaps, some local and chronological variants of $E$. ctenoides could be maintained as subspecies: E. ctenoides vireti, E. ctenoides tetraceros, and E. ctenoides tegulensis $(=E$. darestei $;=E$. senezensis $;=E$. falconeri). Apparently, E. ctenoides ctenoides from Upper Valdarno Basin possess the primary type of antler morphology with respect to more evolved antlers of $E$. ctenoides tegulensis with less pronounced metamery, and slim antlers of E. ctenoides tetraceros, which possibly evolved in the direction of degeneration or under the conditions of starvation.

\section{"Dama-like" deer}

The arbitrary term "Dama-like" deer was used for long time for Plio-Pleistocene small-sized deer with uncertain generic position. Azzaroli (1992) proposed a solution of this taxonomic problem by introducing a new genus name for all Villafranchian small-sized deer of Western Europe, the genus Pseudodama, typified by Dama nestii from Early Pleistocene of Italy. According to AzZAroli (1992), the genus Pseudodama includes a single lineage of several small-sized Villafranchian deer similar to modern fallow deer: Dama nestii, Cervus pardinensis, Cervus rhenanus, Pseudodama lyra and Pseudodama farnetensis. However, GRUBB (2000) argues that Pseudodama Azzaroli, 1992 is preoccupied by Cervus (Metacervocerus) DIETRICH, 1938 with type species Cervus pardinensis. The taxonomical problem appears to be more confused because, according to cranial morphology and ontogenetical development of antlers, Pseudodama is a polythiletic group that includes the earliest in Europe representatives of Cervus ( $C$. nestii) and Dama (D. eurygonos), and another Rusa-like lineage that may be grouped under the genus name Metacervocerus (M. pardinensis, M. rhenanus) (CROITOR, 2006). In this case, the genus name Pseudodama should be restricted to its type species Dama nestii, and therefore, Pseudodama is a junior synonym of Cervus Linnaeus (CROITOR, 2006).

\section{Cervus nestii (AzZAROLI, 1947).}

According to AzZAROLI (1992), Forsyth MAJOR (1879) proposed the species name "Cervus Nestii", which was not accompanied by a species description, a type designation and a describing figure, therefore, the original citation of the species name was regarded as invalid. AzZAROLI (1947) proposed the description of subspecies Dama nestii nestii F. Major and figured its type specimen. Later on AzzAROLI (1992) suggested that the authorship of the species "nestii" belongs to AzzAROLI, 1947, since FORSYTH MAJOR's "Cervus Nestii” is a nomen nudum. The formal diagnosis of the species was proposed by CROITOR (2006). AzZAROLI (1947) regarded the species under study as an ancient fallow deer. Later, Azzaroli (1992) designated Dama nestii nestii as a type species of the genus Pseudodama, which was considered close to the modern genera Axis and Dama. AzzARoli (1992) attributed also to the new genus the species Cervus pardinensis, $C$. rhenanus $(=C$. philisi), $C$. perolensis and two new species Pseudodama lyra AzZARoLI, 1992 and P. farnetensis Azzaroli, 1992. DE Vos et alii (1995) ascribed the species with three pointed antlers (pardinensis and rhenanus) to the genus Cervus, while the species with four-pointed antlers (nestii and farnetensis) are retained to belong to the genus Pseudodama. Di STEFANO \& Petronio (1998) created the new genus Euraxis with type species Dama nestii nestii for the Villafranchian small-sized deer and suggested their close relationship to the actual Asian Axis. VAN DER MADE (1999) reasonably indicated that Euraxis is a junior synonym of Pseudodama by definition.

Cervus nestii is a rather medium-sized deer and the smallest representative of the genus Cervus (the estimated body mass is about $70 \mathrm{~kg}$ ) characterised by comparatively primitive four-pointed antlers and the typical for red deer cranial morphology (CROITOR, 2006). The type specimen IGF 363 (fig. 19) is a pair of antlers that belongs to a mature individual. AzzAROLI (2001) suggested that the type specimen of Cervus nestii is a juvenile individual, however, its pedicles are comparatively shorter than pedicles in some other specimens, which undoubtedly belong 


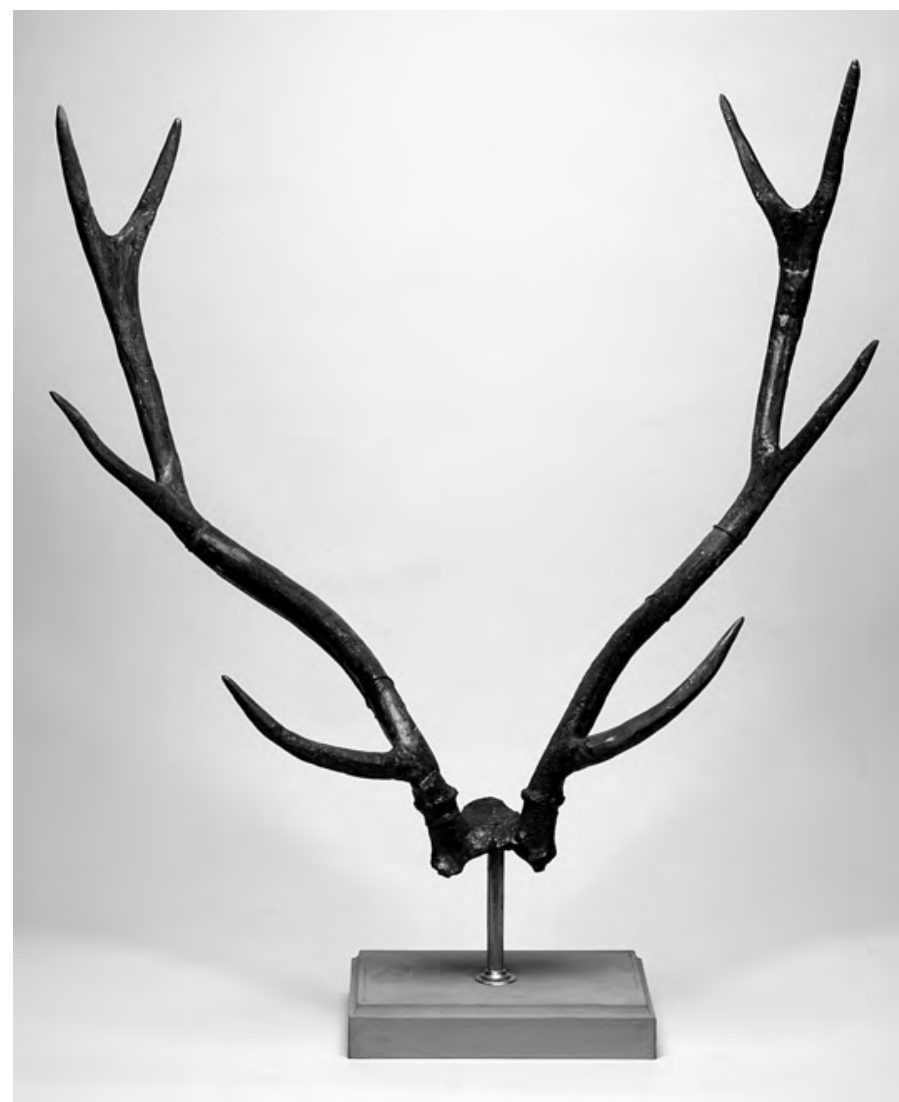

Fig. 19 -Cervus nestii antlers, type specimen of the species, from the Grand duke collections in the Florence Museum.

to juvenile individuals (CROITOR, 2006). The antlers of holotype are thin, long and four-pointed. The antlers of $C$. nestii remind the most primitive subspecies of modern red deer (Cervus elaphus barbarus from North Africa and C. elaphus corsicanus from Corsica and Sardinia). The antlers of the first red deer subspecies of modern type $C$. elaphus acoronatus and the primitive modern subspecies $C$. elaphus bactrianus have the additional bez tine, however they maintain the similar distal fork oriented in the frontal plane. It is very important to mention that C. elaphus bactrianus is characterized by the shortest predental part of the cranium among the modern subspecies of red deer (HEPTNER \& TZALKIN, 1947; FLEROW, 1952) that approach the Bactrian red deer to $C$. nestii. Thus, $C$. nestii should be regarded as one of the earliest representative of the "elaphus" group.

The antlered skull of young adult male IGF 243 from Figline (fig. 20) described and figured by AzzARoLI (1992: p. 16, Pl. 6, fig. 2) is a very interesting finding that, despite it is partially distorted and damaged, brings important cranial characters revealing systematical position of Nesti's deer. The skull belongs to a young adult individual with fully erupted permanent dentition. The braincase is unflexed with flattened parietal bones. The facial portion of skull is relatively long as in modern red deer. The face of $C$. nestii is relatively longer than in Dama dama, Axis porcinus, C. nippon and slightly longer than in $C$. elaphus corsicanus. The relative length of face of the specimen under study is close to the actual southern subspecies of red deer $C$. elaphus bactrianus and C. elaphus maral.

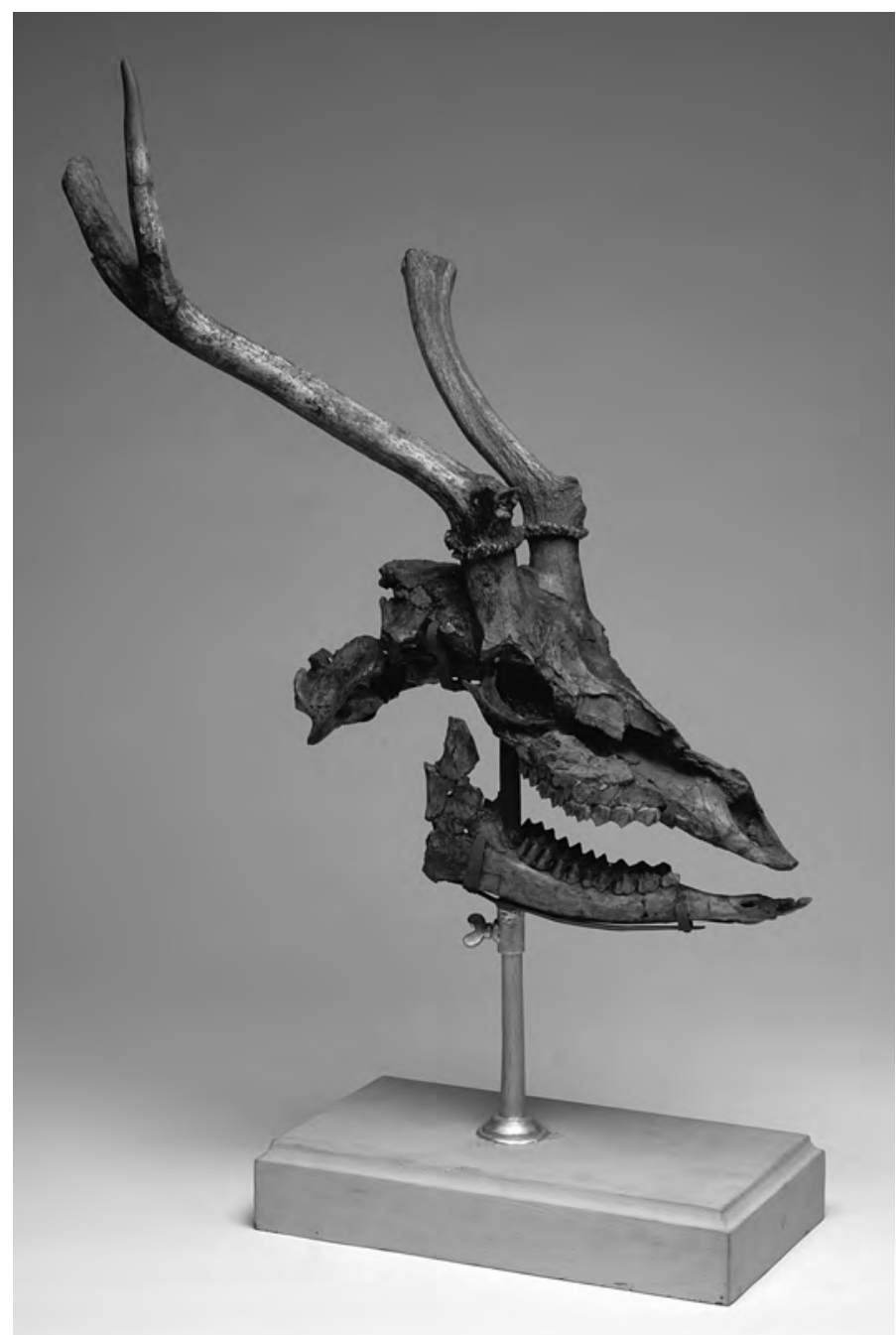

Fig. 20 - Cranium and jaw of a young specimen of Cervus nestii. The specimen has been recovered in the surrounding of Figline (Upper Valdarno Basin) in 1873.

\section{Dama eurygonos (AzZAROLI, 1947).}

AzZAROLI (1947) introduced the subspecies Dama nestii eurygonos followed by a description and a figure of type specimen. PETRONIO (1979) confirmed validity of the subspecies Dama nestii eurygonos. Later, AzzAroli (1992) in his revision of small-sized deer of Tuscany, ignores the name "eurygonos". As Azzaroli noted later (AzzAROLI, 2001), the type of Dama nesti eurygonos represents an adult stage of antler development of Dama nestii [nestii], which, in its turn, is typified by a juvenile individual. However, a part of rather fragmented cranial material from Upper Valdarno Basin indicates the presence of a typical representative of modern genus Dama characterized by short and rounded braincase, short (even in young individuals) pedicles with incranial position, large orbits, short orbito-frontal portion of skull, and large ethmoidal fissures (CROITOR, 2006).

\section{Bovidae (RC)}

The genus Leptobos characterized Villafranchian assemblages of Eurasia with different species, some of which (since the first description by RÜTYMEYER in 1878; 


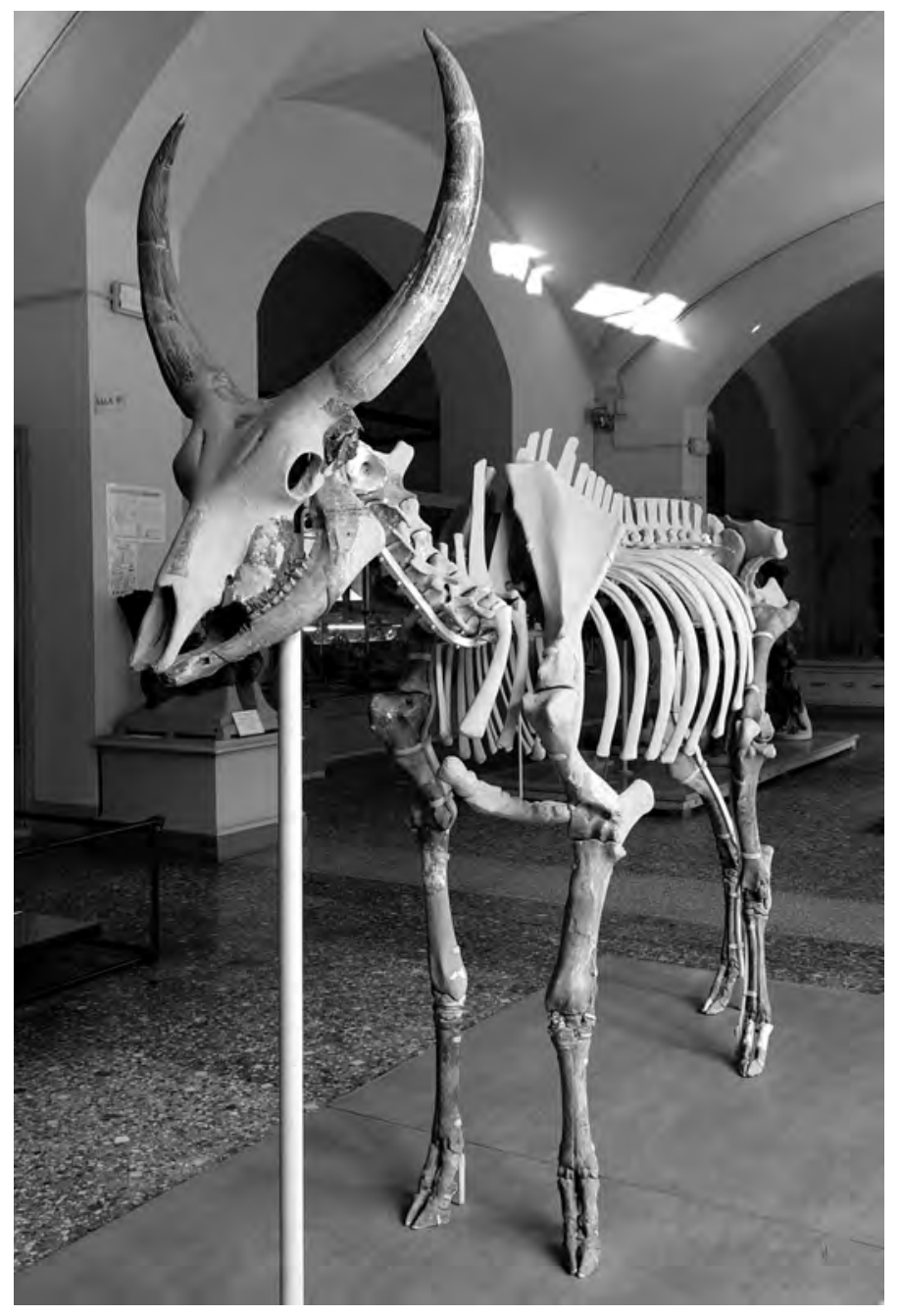

Fig. 21 - Leptobos etruscus, mounted skeleton in the exhibition hall of the Florence Museum. G. Merla has described the specimen in a monographic work dated 1949.

cfr. Rook, 2012) have been object of debate and/or are considered as belonging to different subgenera (MASINI, 1989; DuvernoIs, 1990). The Upper Valdarno Basin sedimentary succession yielded a number of remains of the genus, including type specimens of two of the betterknown species of the European Early Pleistocene.

\section{Leptobos etruscus (FALCONER, 1859).}

The Scottish naturalist Hugh Falconer (well known for his studies on the mammalian fossils of the Siwalik Hills, India) in the 1850s had occasion to study the palaeontological collections of the Florence Museum and described some element of the Tuscan fossil fauna (CIOPPI \& Dominici, 2010). FALCONER first recognised the occurrence of a new species of bovid (different from Bos primigenius), in the Upper Valdarno Basin record and named it "Bos etruscus" in a manuscript in 1859. The specific name has been formally published a few years later (FALCONER, 1868) in a postumous paper. MERLA (1949) was the first who provided an exhaustive description and illustration of the species (figs. 4, 21).

Leptobos etruscus is a rather large but comparatively gracefully build bovine form (CROITOR \& BRUGAL, 2007). The sexual dimorphism is observed in cranial morpho- logy, since horn cores are evolved only in males. The holotype of $L$. etruscus is a perfectly preserved complete skull in articulation with lower jaw IGF 612 of an adult male. The horn cores are inserted close to orbits, with rounded cross-section, long, directed backward and sideward, then bended inward, situated in the plane of frontals. Horn core pedicles are long, robust and slightly compressed dorso-ventrally. Frontal bones are broad and flat, with some-what depressed their median part. Nasal bones are narrow and short and do not reach the imaginary line connecting the anterior edges of orbits. The contact between premaxillary and nasal bones is long. The shape of premaxillary bones is rather rectangular with slightly rounded anterior margins, and just a little broadened in their anterior part. The parietal part of cranium is long, facial part is comparatively short, shorter than in Bison. Unlike Eobison tamanensis from Early Pleistocene site Semibalki, Russia (which still remains undescribed: BAJGUSHEVA, 2000), Leptobos together with Bison have short and narrow nasal bones. The horizontal body of lower mandible is high; the area of insertion of musculus masseter barely reaches the level of posterior edge of $\mathrm{M}_{3}$. Processus angularis is moderately developed. Limb bones, especially metacarpals, are comparatively long and slender.

The oldest Leptobos of the "etruscus group", L. brevicornis and L. crassus, are reported from Late Pliocene (2.55 Ma and 2.4 Ma correspondingly) of China (DoNG, 2008). Remains of Leptobos etruscus are reported from MN18 of Spain, France, Italy, Greece, and Romania (Merla, 1949; Duvernois, 1990, Kostopoulos, 2006; GARRIDO, 2008; CROITOR \& POPESCU, 2011). BURCHAKABRAMOVICH \& VEKUA (1980) described a horn core of Leptobos sp. from Kotzahuri (Late Pliocene-Early Pleistocene, Georgia) similar to horn core of L. etruscus from Upper Valdarno. L. etruscus, most probably, arrived in Europe from Caucasus and, apparently, was better adapted to mountain forest biotopes. Rather long horn cores of $L$. etruscus combined with the large body size corresponds to a forest dweller according to the classification of KöHLER (1993: fig. 5). One can assume implication of L. etruscus in the intraspecific ritualized combats, but no doubts the long and slightly curved horns of L. etruscus were an effective defence weapon against such woodland predators, like, for instance, saber-toothed felids.

L. etruscus is characterized by rather broad intermaxillary bones; the comparatively short face before orbits; and the quite short anterior part of face if compared to modern African savannah antelopes of the same size (SPENCER, 1995; MARTÍNEZ-NAVARRo et alii, 2007). The extremely long face in some African antelopes like Alcelaphus buselaphus or Connochaetes taurinus, apparently, is an adaptation to the grazing in the tall grass that allows to keep the animal's eyes above the grass level and to observe the possible danger (predators, etc.) (KöHLER, 1993). The short face in combination with broad premaxillar bones suggest that L. etruscus was rather a woodland or forest mixed feeder with broad spectrum of food sources.

\section{Leptobos vallisarni (MERLA, 1949).}

Merla (1949) based his new species Leptobos vallisarni from Upper Valdarno Basin on specific shape of its short and robust horn cores. According to DUVERNOIS (1990), L. vallisarni represents an individual short-horned variant of L. etruscus. DUVERNOIS \& GUÉRIN (1989) pro- 
posed a new species name for a smaller form of Leptobos that coexisted with $L$. etruscus in the fauna from Senéze. GARRIDO (2008) regards the characters of dental morphology used by DUVERNOIS \& GUERIN (1989) for definition of $L$. furtivus as individual morphological variants of $L$. etruscus, and therefore L. furtivus should be regarded as a junior synonym of L. etruscus. GeNTILI \& MASINI (2005) reported a good sample of Leptobos aff. vallisarni from Pietrafitta (Italy) that proves a rather constant character of horn core length and shape characteristic of L. vallisarni. According to Kostopoulos (2006), "Leptobos" (sic!) vallisarni is a primitive bison, grouped together with Eobison.

L. vallisarni is as large as the previous species. The holotype of L. vallisarni is a male horned skull IGF 622 (fig. 22) that allows a direct comparison with L. etruscus. The skull belongs to a very old individual with deeply worn cheek teeth. General proportions of the skull are shortened if compared to L. etruscus (BUKHSIANIDZE, 2005). Nasal and premaxillary bones are destroyed. Nasal bones, apparently, did not reach the imaginary line connecting the anterior edge of orbits.

The horn cores provide the main diagnostic characters. The horn cores are short, more massive and stronger compressed dorso-ventrally if compared to L. etruscus. They are stronger diverged and form with the cranial axis an angle of $57^{\circ}$. The pedicles of horn cores are significantly compressed dorso-ventrally. The posterior side of the horn core is more rounded than the anterior side; therefore the cross-section of the proximal part of the horn core is ovoid in shape. The horn cores are placed in the frontal plane, curved medially with a slight torsion. The horn core tips are pointed backward and slightly inward.

L. vallisarni is known only from the Italian peninsula so far (MERLA, 1949; Gentili \& MASINI, 2005), reported from sites in Upper Valdarno Basin, Val di Chiana Basin, and Pietrafitta. Apparently, such a small area of distribution limited by natural zoogeographic obstacles like Alps and sea shores, suggests the endemic character of species (CROITOR \& POPESCU, 2011). L. etruscus is a direct forerunner of L. vallisarni (MAsini, 1989; BukHSIANIDZE, 2005). Kostopoulos' (2006) opinion that L. vallisarni could be a primitive bison is questionable. Unfortunately, the well-preserved partial cranium of Eobison tamanensis from Semibalki (South Russia) reported by BAJGUSHEVA (2000) remains undescribed, therefore we cannot illustrate comparison of cranial morphology, which would be very useful in this case. According to the face morphology, Eobison of Tamanian type can not be a transitional form between Leptobos and Bison, since it is characterized by very large and broad nasal bones that represent a derived condition. On the contrary, nasal bones of L. vallisarni and modern Bison are short and narrow. However, L. vallisarni looks as a specialized open-landscape species with a series of adaptations that superficially remind the bison-like ecotype. During the latest Villafranchian, the ecological niche of a large open country ruminant herbivore remained unfilled in Italian Peninsula due to the Dinaric zoogeographical filter (CROITOR \& POPESCU, 2011). Apparently, L. vallisarni evolved in the process of colonization by L. etruscus of the unfilled ecological niche of large open-landscape ruminant.

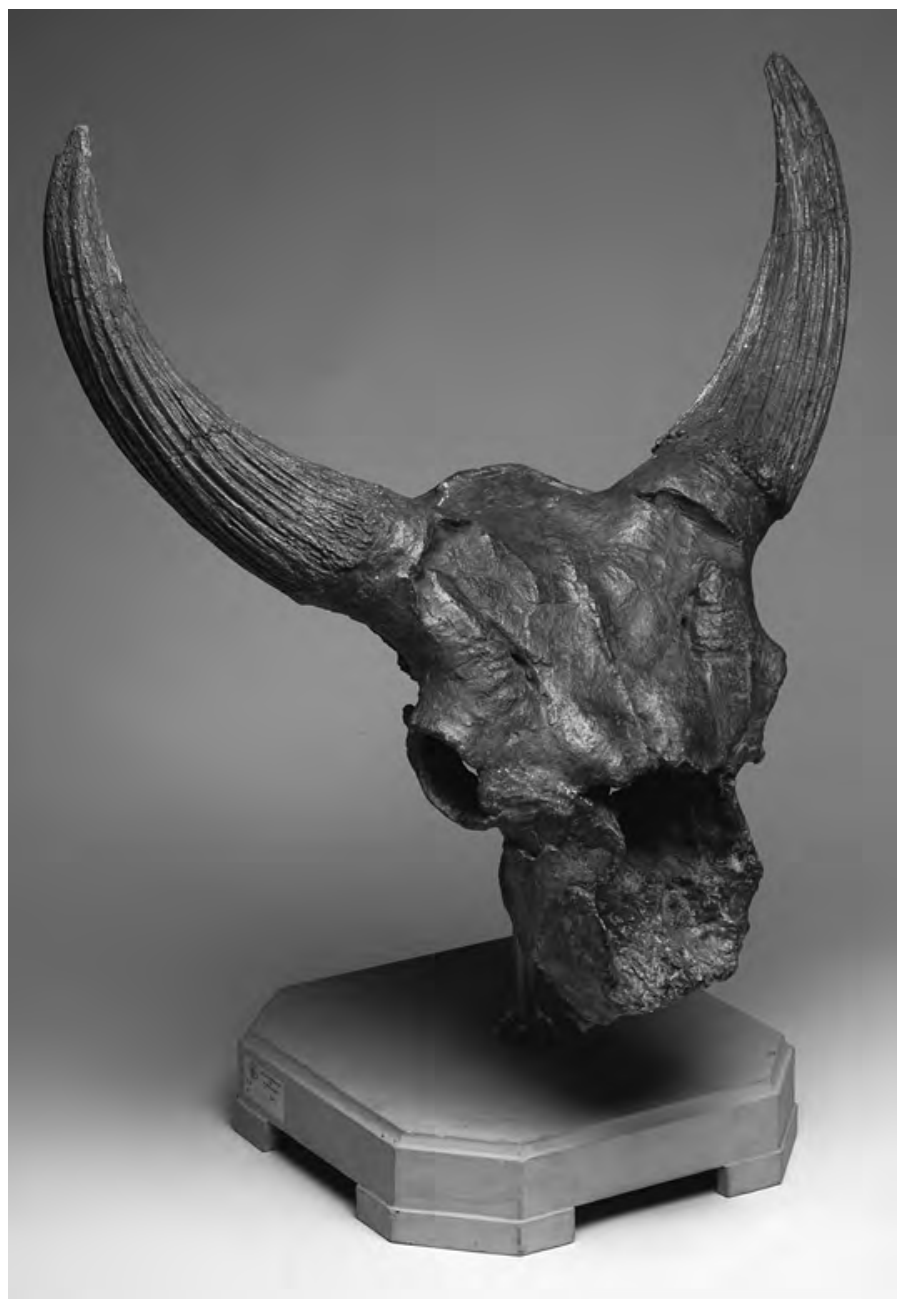

Fig. 22 - Leptobos vallisarni cranium, type specimen of the species erected by $\mathrm{G}$. Merla in 1949.

\section{Perissodactyla (LR)}

The three extant perissodactyl families are known from the Plio-Pleistocene fluvio-lacustrine strata of the Upper Valdarno Basin. As for other groups, different species or species associations characterize the three main depositional sequences of the Upper Valdarno Basin. The occurrence in Castelnuovo dei Sabbioni Synthem sediments of a fossil species of tapir (Tapirus arvernensis), and the early rhino Stephanorhinus jeanvireti, characterises the Early Villafranchian Triversa Faunal Unit. The faunal assemblages recorded in sediments from the Montevarchi Synthem, are instead characterised by the disappearance of these previous species, and by the occurrence of two monodactyl horses (Equus stenonis and Equus stelhini) and by the typical rhino Stephanorhinus etruscus. The appearance of new grazers, such as Stephanorhinus hemitoechus and Equus süssenbornensis characterises the faunal assemblages found in the Torrente Ciuffena Synthem.

\section{Tapiridae}

The genus Tapirus seems to appear in Europe around the Early-Middle Miocene. In the Middle and Late Miocene, the genus dispersed widely and its occurrence is 


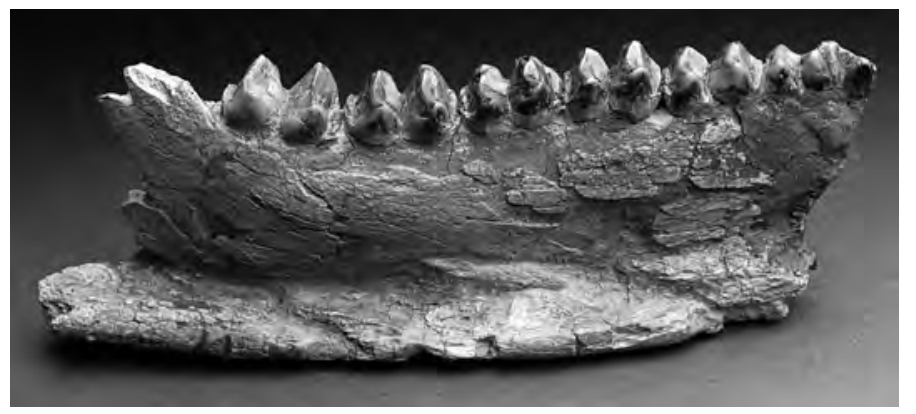

Fig. 23 - Tapirus arvernenis mandible from the lignite mine of Castelnuovo dei Sabbioni, Arezzo.

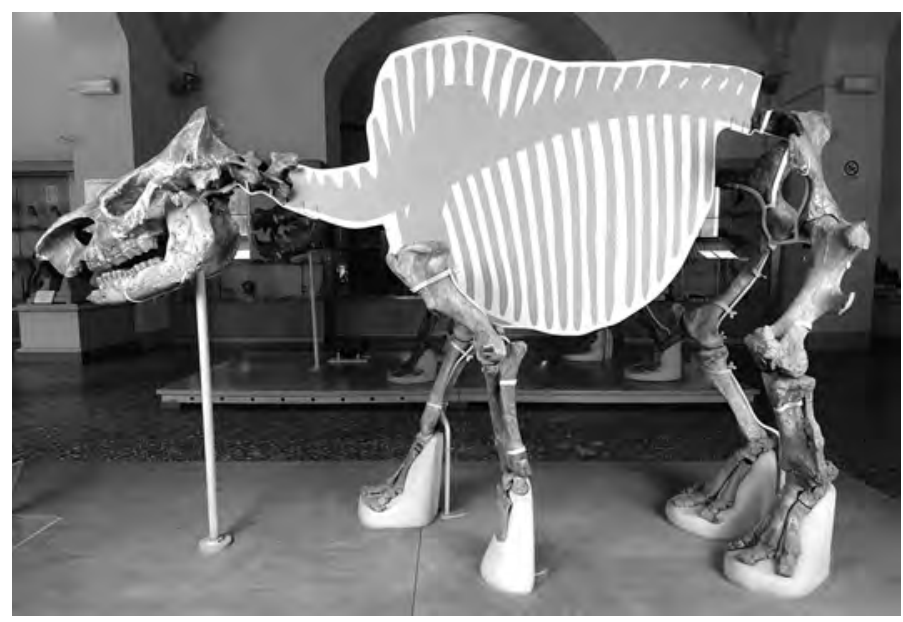

Fig. 24 - Stephanorhinus etruscus, partial (compiled) articulated skeleton. Limb bones have been collected at the locality "Poggio al Pero" by Filippo Nesti in 1811, cranium and mandible are from collections by A. Azzaroli in the 1950's

testified in several Western European sites. Tapirus arvernensis appeared and dispersed in Western Europe during the latest Miocene and Pliocene as testified by the remains recovered from several sites across Europe (RUSTIONI, 1992). This species is smaller and more slenderly than the present-day and extinct species. Nevertheless in its cranial characters, $T$. arvernensis clearly recalls $T$. indicus. Rustioni (1992) postulated that the European and Asian lineages are offsprings from a common Miocene stock. In Italy a number of Pliocene sites are known to have yielded tapir remains. Tapirus arvernensis definitively disappeared from Europe during the Late Pliocene at the time of the transition from the Faunal Unit Triversa to the Faunal Unit Montopoli within the large Mammal biochronologic scale. The fossils from Castenuovo dei Sabbioni (fig. 23) representing one of the last occurrences of the genus in Europe (GLIOZZI et alii, 1997; PRADELLA \& RoOK, 2007).

\section{Rhinocerotidae}

Several authors have debated the evolutionary history of the genus Stephanorhinus. The genus was erected by KRETZOI in 1942 referring to the European Plio-Pleistocene incisorless rhinoceroses. While regarded as invalid by GUERIN (1980), the genus Stephanorhinus, has been reintroduced by FoRTELIUS et alii (1993) based on a critical revision of western European fossil record.

Stephanorhinus jeanvireti emerged from the beginning of the Late Pliocene and coexisted with S. etruscus for a short time (LACOMBAT, 2007). S. jeanvireti occurrs in the Castenuovo dei Sabbioni Synthem, and is only known, so far, from the Early Villafranchian of Europe. It is a slender, medium- to large-sized rhino, showing brachydont teeth and long slender limb bones and metapodials, suggesting cursorial proportions.

The rhino species that is found as a relatively common taxon in deposits of the Montevarchi Synthem is S. etruscus, actually one of the most characteristic elements in the Late Villafranchian of Europe (like Equus stenonis among equids, see below). The type specimen of this species (erected in 1868 by Hugues Falconer) is a skull from the Upper Valdarno Basin old collections. This species is characterized by brachydont teeth and post-cranial bones relatively less slender than the previous one. The partial articulated skeleton in exhibit at the Geology and Paleontology Section of the Natural History Museum of the University of Florence (fig. 24) has been collected at the locality "Poggio al Pero" by Filippo Nesti in 1811. The relation between $S$. jeanvireti and $S$. etruscus appears to ForTELIUS et alii (1993) to be a non-resolvable question.

In Early and Middle Pleistocene times two different rhino species occurrs in the European fossil record. The small browser $S$. hundsheimensis has been indicated in literature with several names as Dicerorhinus etruscus brachycephalus or Dicerorhinus hemitoechus intermedius. Stephanorhinus hundsheimensis is typical of the Late Villafranchian (in Spain it is recorded at Venta Micena, Fuente Nueva-3, Barranco León: LAcomBAt, 2010), but also found in the base of the Middle Pleistocene (Galerian; GLIOZZI et alii, 1997; FICCARELLI et alii, 1997). It shares a number of dental and postcranial features with $S$. etruscus, which attests to a possible descent from the latter species (MAzzA et alii, 1993; LACOMBAT, 2010). The second Middle Pleistocene species (extending its range into the Late Pleistocene) is Stephanorhinus hemitoechus. Its first occurrence is doubtful because the most ancient specimens attributable to $S$. hemitoechus are of stratigraphically problematic provenance, such as the partial mandible labelled from "Croce dei Cappuccini" in the Upper Valdarno Basin (FoRTELIUs et alii, 1993). Although this specimen (as well as other specimens from different Pleistocene basins in Tuscany) lacks clear stratigraphic provenance, its occurrence could indicate that $S$. hemitoechus appeared in Europe already within the Early Pleistocene. S. hemitoechus was a short-limbed, graviportally structured grazer, characterized by hypsodont molars. S. hemitoechus probably was the ecological equivalent, in the steppe environment, of the tundra rhinoceros Coelodonta antiquitatis, with which it shares a number of analogies.

\section{Equidae}

The genus Equus dispersed in Europe around 2.6 m.y. ago and its occurrence marks the so-called "Elephant/ Equus event" as defined by Azzaroli (1977b, 1883). Equus livenzovensis, the first representative of the genus in Europe is considered a distinct species from E. stenonis. Its occurrence is not registered in Upper Valdarno Basin, but is present with a few and fragmentary remains 


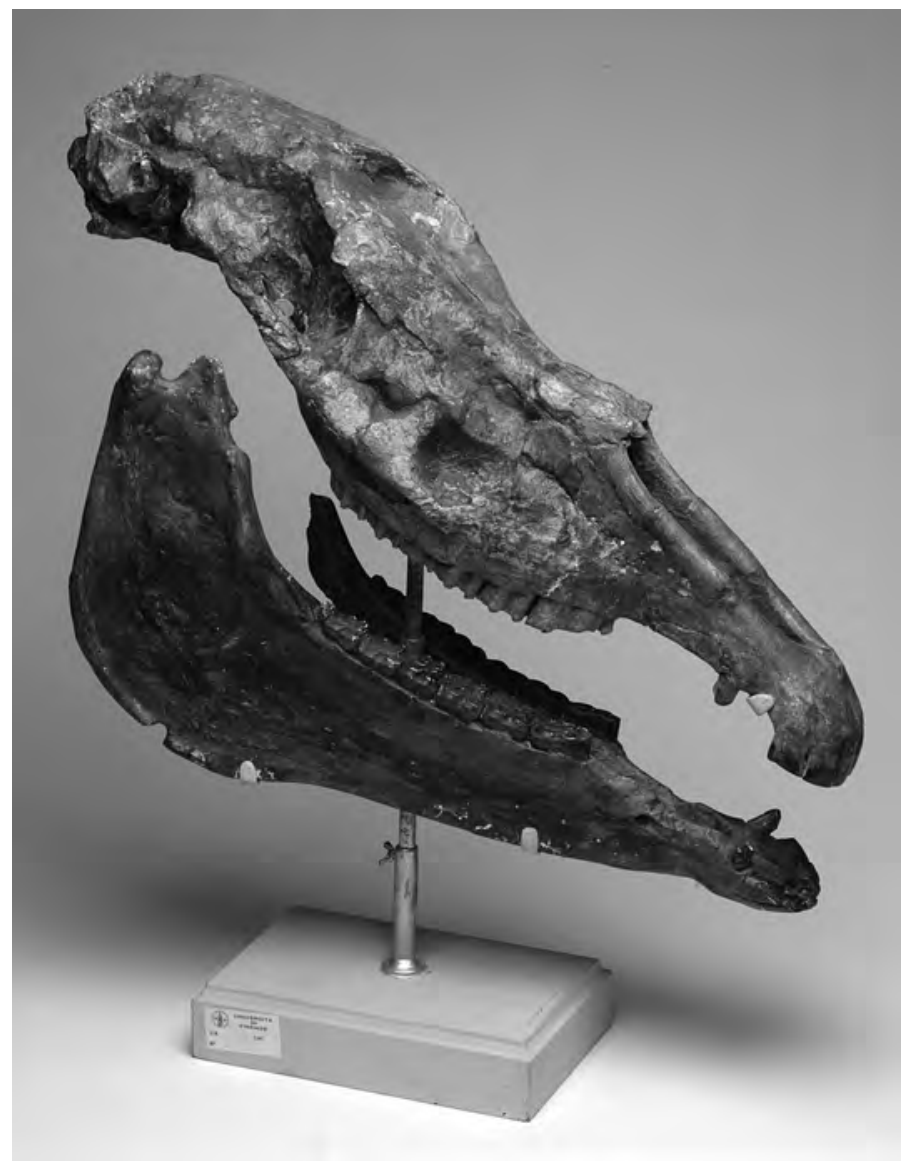

Fig. 25 - Equus stenonis. This skull, the type specimen, comes from an unregistered locality in the surroundings of Terranova.

at Montopoli in Lower Valdarno Basin (Montopoli F.U., Middle Villafranchian), in deposits aged about $2.5 \mathrm{~m} . \mathrm{y}$ (LINDSAY et alii, 1980; BENVENUTI et alii, 1995).

Equus stenonis, presumably derived from E. livenzovensis, appears in Europe at the transition with St. Vallier F.U. (ALBERDI et alii, 1998). This species is characterized by a large geographic and temporal distribution, and is a common element within the Montevarchi Synthem deposits (fig. 25). CoccHI (1867) erected the species on material from Terranova in Upper Valdarno Basin (DE GIULI, 1972).

A second horse species occurring in the Montevarchi Synthem is Equus stehlini. The latter is a form of uncertain interpretation for its very restricted diffusion, either geographical (apparently only Tuscany), as well as temporal (its distribution is confined to the beginning of the Late Villafranchian, Olivola and Tasso F.U.). The type specimen of this species also comes from an unrecorder locality nearby Terranova, in Upper Valdarno Basin (AzzAROLI, 1965). Although similar to E. stenonis, the species is easily recognizable for its reduced size, some "asinine" characters of the skull which otherwise displays general stenonoid morphology.

Finally, at the end late Early Pleistocene appears a very large horse (the largest known of the genus Equus), a form that seems to survive in Italy until Late Galerian. This species shows derived dental features and attenuate stenonoid morphology in limb bones. Many authors recognized two different large-sized species, one typical of

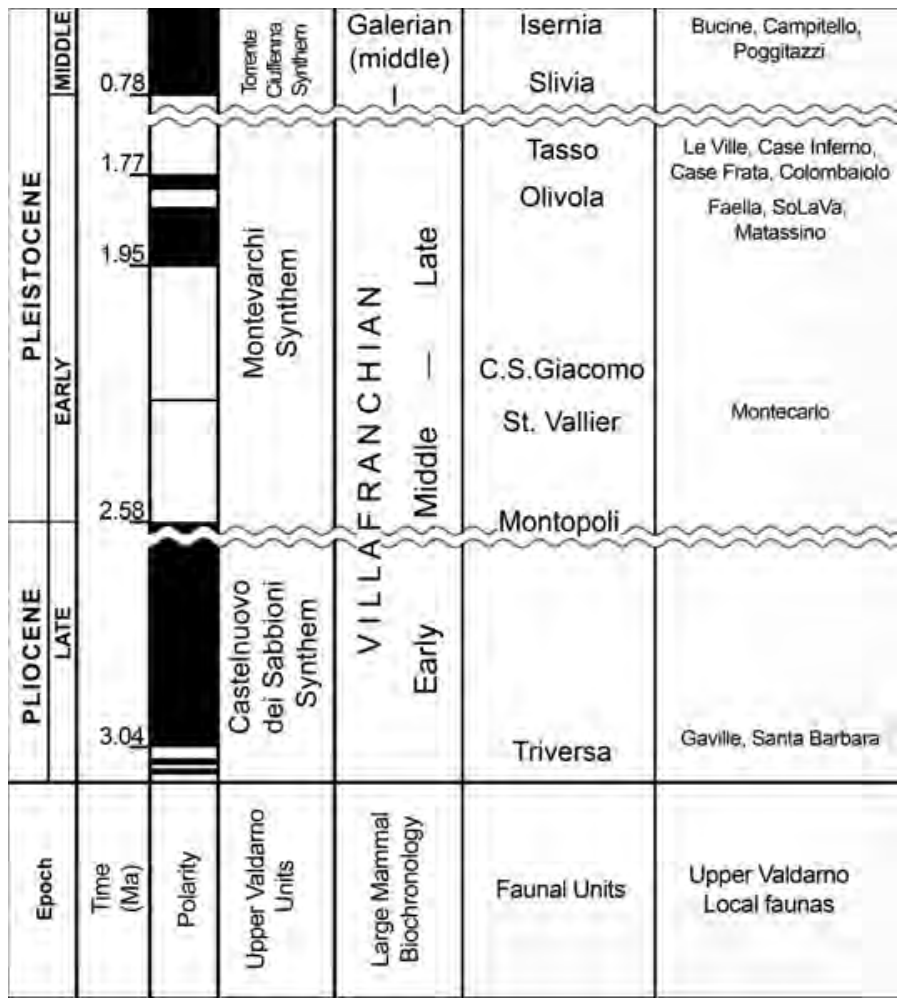

Fig. 26 - Upper Valdarno Basin stratigraphic units (from FIDOLINI et alii, 2013; NAPOLEONE et alii, 2003), combined with Villafranchian chronology, Biochronological units (Faunal Units) and stratigraphic position of Upper Valdarno Basin Local Faunas mentioned in the text.

Late Villafranchian faunal contexts, E. bressanus, and the other characteristic of Early Galerian assemblages, E. süssenbornensis. Nevertheless, the characters used to separate the two species are considered insufficient, and commonly the large-sized Late Villafranchian-Early Galerian equids of Europe are referred to E. gr. bressanussüssenbornensis. In Upper Valdarno Basin this species is recorded only by some teeth, from not precisely datable deposits, belonging to the more recent deposits (Torrente Ciuffenna Synthem).

\section{CONCLUSIVE REMARKS}

The Upper Valdarno Basin vertebrate fossil record is unique, both in terms of amount of fossil remains yelded, as well as in terms of historical significance of a huge number of collections, build up along the last 500 years. Upper Valdarno Basin record is the basis for taxonomic definition of much of the Plio-Pleistocene (Early to Late Villafranchian) species and genera, as well as for the definition of biochronological subdivisions of the continental biochronologic scale (fig. 26).

The Castelnuovo dei Sabbioni Synthem yelded the celebrated Local Fauna of Santa Barbara (Late Pliocene, Early Villafranchian, Triversa Faunal Unit). The Montevarchi Synthem covers a long time span encompassing part of the Middle and most of the Late Villafranchian. The Middle Villafranchian tends to be elusive, although isolated remains with unknown provenance from old collections suggest the occurrence of this biochornologic 
unit. The occurrence of the vole Mimomys polonicus (Late Villaniyan; Middle Villafranchian) from Montecarlo (GHINASSI et alii, 2005; RoOK \& ANGELONE, 2013) is a crucial evidence confirming the occurrence within the Upper Valdarno Basin infill of fossiliferous deposits yielding Middle Villafranchian faunas, as it was suggested by the aforementioned occurrence, for instance, of the proboscidean Anancus arvernensis in the "vicinity of Montecarlo monastery". The uppermost portion of the Montevarchi Synthem is made up of the sediments that yielded the majority of the vertebrate record of the Upper Valdarno Basin. The extensive vertebrate record allows to recognize here two different Faunal Units in succession: $i$ ) the Olivola F.U., represented by assemblages from Local Faunas such as SoLaVa (a brick factory near Figline Valdarno), Matassino, and Faella; ii) the Tasso F.U., represented by a cluster of Local Faunas such as Tasso (after which the F.U. is named), Le Strette, Case Fratta, Case Inferno, Le Ville, Colombaiolo and others. Finally, the Torrente Ciuffenna Synthem contains a few localities that yielded mammal faunas typical of the "post-Villafranchian" (Early Galerian; GLIOZZI et alii, 1997; TORRE et alii, 2001). The better-known sites are in the southeastern portion of the Basin (Bucine, Campitello), while in the old collections are present taxa like E. gr. bressanussüssenbornensis from unrecorded sites (AzZAROLI, 1984) or the vole Arvicola cantiana from Poggitazzi (TorRe, 1985; RoOK \& ANGELONE, 2013).

It is certainly true that label errors and uncertainties on exact stratigraphic provenance may be source of doubts and perplexities, especially for what concerns the old historical collections. As a matter of fact, however, new collections, and excavations of controlled fossil samples in the Upper Valdarno Basin, may allow significant improvement of our knowledge on stratigraphic, taxonomic, and biochronological characterisation of historical material.

\section{ACKNOWLEDGMENTS}

We thank Mario Sagri and Massimiliano Ghinassi for inviting us to contribute within this special volume. We dedicate this paper to Prof. Augusto Azzaroli, in recognition of his fifty-year-long research activity on Upper Valdarno Plio-Pleistocene mammals. Elisabetta Cioppi (Geology and Palaeontology Section of the Natural History Museum, University of Florence) provided access to collections and Museum archives. The photographic images enriching this paper are by Saulo Bambi (Natural History Museum, University of Florence). MD acknowledge SYNTHESYS Project (AT-TAF-1281) for the study of extant comparative material of chelonians at Naturhistorisches Museums Wien (Austria). RC research on Florence collections was supported by two CNR-NATO Advanced Fellowships, in 1999 and 2005. MP thanks Sergio Gentili (Perugia) for access to the fossil birds from Pietrafitta mine.

\section{REFERENCES}

Alba D.M., Moyà-Solà S., Madurell J. \& Aurell J. (2008) - Dentognathic remains of Macaca (Primates, Cercopithecidae) from the late early Pleistocene of Terrassa (Catalonia, Spain). J. Hum. Evol., 55, 1160-1163.

Alba D.M., Calero J.A.C., Mancheño M.A., Montoya P., Morales J. \& RoOK L. (2011) - Fossil remains of Macaca sylvanus fiorentina (CocCHI, 1872) (Primates, Cercopithecidae) from the Early Pleistocene of Quibas (Murcia, Spain). J. Hum. Evol., 61, 703-718.

Alberdi M.T., Ortiz-Jaureguizar E. \& Prado J.L. (1998) - A Quantitative Review of European Stenonoid Horses. J. Paleont., 72, 371-387.
Agustí J. \& Rook L. (2011) - Neogene Mammalian Successions and Dispersals. Homage to Pierre Mein. Géobios, 44, 2-3.

Azzaroli A. (1947) - I cervi fossili della Toscana. Palaeont. Ital., 43, 46-81.

Azzaroli A. (1952) - Sul recente ritrovamento di uno scheletro di Elephas meridionalis presso Montevarchi. Mem. Vald., ser. V, 1, 47-52.

Azzaroli A. (1953a) - Filogenesi e biologia di Sus strozzii e di Sus minor. Palaeont. Ital., 48, 41-76.

Azzaroli A. (1962) - Rinoceronti Pliocenici del Valdarno Inferiore. Palaeont. Ital., 57, 11-20.

Azzaroli A. (1965) - The two Villafranchian Horses of the Upper Valdarno. Palaeont. Ital., 59, 1-12.

Azzaroli A. (1966) - La Valeur des Caractéres Cràniens dans la Classification des Eléphants. Ecl. Geol. Helv., 59, 541-564.

Azzaroli A. (1970) - Villafranchian correlations based on large mammals. Giorn. Geol., 35 (1967), 111-131.

AzzAROLI A. (1977a) - Evolutionary patterns of Villafranchian Elephants in Central Italy. Atti Acc. Naz. Lincei, Mem. Cl. Sci. Fis., 14 (8), 149-168.

Azzaroli A. (1977b) - The Villafranchian stage in Italy and the PlioPleistocene boundary. Gior. Geol., 41, 61-79.

Azzaroli A. (1983) - Quaternary Mammals and the End-Villafranchian Dispersal event - a turning point in the history of Eurasia. Palaeogeography, -ecology, -climatology, 44, 117-139.

Azzaroli A. (1984) - On some Vertebrate remains of middle Pleistocene age from the Upper Valdarno and Val di Chiana, Tuscany. Palaeont. Ital., 73, 104-115.

Azzaroli A. (1988) - The paleontological work of Giovanni Merla. Mem. Soc. Geol. It., 31 (1986), 129-130.

Azzaroli A. (1992) - The cervid genus Pseudodama n.g. in the Villafranchian of Tuscany. Palaeont. Ital., 79, 1-41.

AzZaroli A. (2001) - On fossil deer from the Valdarno, Tuscany, Italy (Comments on a paper by Di Stefano \& Petronio). Neues Jahr. Geol. Paläont., 2001 (3), 168-174.

Azzaroli A., De Giuli C., Ficcarelli G. \& Torre D. (1982) - Table of stratigraphic distribution of terrestrial mammalian faunas in Italy from the Pliocene to the early Middle Pleistocene. Geogr. Fis. Dinam. Quat., 5, 55-58.

Azzaroli A., De Giuli C., Ficcarelli G. \& Torre D. (1988) - Late Pliocene to early mid-Pleistocene mammals in Eurasia: faunal succession and dispersal events. Palaeogeography, -ecology, -climatology, 66, 77-100.

Azzaroli A. \& Mazza P. (1992) - The cervid genus Eucladoceros in the early Pleistocene of Tuscany. Palaeont. Ital., 79, 43-100.

BAJgusheva V.S. (2000) - New data on Tamanian faunal assemblage from the excavation near Semibalki Village (Azov Area). Hist. Archaeol. Stud. Azov and Lower Don, 16, 27-57.

Bedetti C. (2003) - Le avifaune fossili del Plio-Pleistocene Italiano: sistematica, paleoecologia ed elementi di biocronologia. PhD Dissertation, University of Roma Sapienza, Roma.

Bedetti C. \& PaVia M. (2004) - The validity of the fossil Aythya aretina (Portis) and Aythya sepulta (Portis) (Aves, Anatidae) on the basis of new finding in the Italian Early Pleistocene. Sixth S.A.P.E. Meeting, Quillan (France), Abstract book, 3-4.

Benvenuti M., Dominici S. \& Rook L. (1995) - Inquadramento stratigrafico-deposizionale delle faune a mammiferi villafranchiane (unita faunistiche Triversa e Montopoli) del Valdarno Inferiore nella zona a sud dell'Arno (Toscana). Il Quaternario, 8, 457-464.

BERggren W.A. \& VAN Couvering J.A. (1974) - The late Neogene: Biostratigraphy, geochronology and paleoclimatology of the last 15 million years in marine and continental sequences. Palaeogeography, -ecology, -climatology, 16, 1-216.

Bertini A. (2013) - Climate and vegetation in the Upper Valdarno Basin (central Italy) as a response to Northern Hemisphere insolation forcing and regional tectonics in the late Pliocene-early Pleistocene. Ital. J. Geosci., 132, 137-148. doi: 10.3301/IJG.2012.18.

Berzi A. (1966) - L'orso di Gaville nel Valdarno Superiore. Palaeont. Ital., 60, 19-32.

BocheŃsKy Z. (1987) - List of European fossil bird species. Acta Zool. Cracov., 40, 293-333. 
Bonini M., Moratti G., Sani F. \& Balestrieri M.L. (2013) - Compression-to-extension record in the Late Pliocene-Pleistocene Upper Valdarno Basin (Northern Apennines, Italy): structural and thermochronological constraints. Ital. J. Geosci., 132, 54-80. doi: 10.3301/IJG.2011.18.

Borselli V., De Giuli C., Ficcarelli G. \& Mazzini M. (1980) Casa Frata: Una località fossilifera del Villafranchiano superiore presso Terranuova Bracciolini (Arezzo) nel Valdarno Superiore. Boll. Soc. Paleont. It., 19, 254-258.

Brodkorb P. (1964) - Catalogue of fossil birds. Part 2 (Anseriformes through Galliformes). Bull. Florida St. Mus., Biol. Sci., 8, 195-335.

Brogi A., Fidolini F. \& Liotta D. (2013) - Tectonic and sedimentary evolution of the Upper Valdarno Basin: new insights from the lacustrine S. Barbara Basin. Ital. J. Geosci., 132, 81-97. doi: 10.3301/IJG.2012.08.

Broin F. De (1977) - Contribution à l'étude des Chéloniens. Chéloniens continentaux du Crétacé et du Tertiaire de France. Mém. Mus. Nation. Hist. Nat. Paris. Sér. C. Sci. Terre, 38, 1-366.

Bukhsianidze M. (2005) - The fossil bovidae of Dmanisi. PhD Thesis, University of Ferrara, 192 pp.

BurchaK-Abramovich N.I. \& VeKuA A.K. (1980) - Paleobiological History of Late Caenozoic Bulls of Caucasus. 91 pp., Tbilisi (Metzniereba).

Cheneval J. (1987) - Les Anatidae (Aves, Anseriformes) du Miocène de France. Révision systématique et évolution. In: Mourer-Chauviré C. (ed.), L'évolution des oiseaux d'après le témoignage des fossiles. Docum. Lab. Géol. Lyon, 99, 137-157.

Cheneval J. (2000) - L'avifaune de Sansan. In: Ginsburg L. (ed.), La faune miocène de Sansan (Gers) et son environment. Mém. Mus. Nation. Hist. Nat. Paris, 183, 321-388.

CHESI F. (2009) - Il registro fossile italiano dei cheloni. PhD Thesis in Earth Sciences, Università di Firenze.

Cioppi E. \& Dominici S. (2010) - Origin and development of the geological and palaeontological collections. In: Monechi S. \& Rook L. (eds.), Il Museo di Storia Naturale dell'Università di Firenze. Volume $3^{\circ}$. Le collezioni geologiche e paleontologiche, 19-55.

Cioppi E., Dominici S. \& Mazza P. (2001) Le collezioni paleontologiche della Marchesa Paulucci conservate presso il Museo di Storia Naturale di Firenze. Museol. Sci., 16, 219-229.

Cocchi I. (1867) - L'uomo fossile nell'Italia Centrale. Studi paleoetnologici. Mem. Soc. It. Sci. Nat., 2 (7), 3-80.

Cocchi I. (1972) - Su di due Scimmie fossili italiane. Boll. R. Com. Geol. It., 3-4, 59-71.

Corsi P. (2003) - La Carta Geologica d'Italia: agli inizi di un lungo contenzioso, pp. 271-300. In: Vai G.B. \& Cavazza W. (eds.), Four Centuries of the Word Geology. Ulisse Aldrovandi 1603 in Bologna. Minerva Edizioni.

CROITOR R. (2006) - Early Pleistocene small-sized deer of Europe. Hellenic J. Geosci., 41, 89-117.

CROITOR R. \& Bonifay M.-F. (2001) - Étude préliminaire des cerfs du gisement Pleistocène inférieur de Ceyssaguet (Haute-Loire). Paleo, 13, 129-144.

Croitor R. \& Brugal P. (2007) - New insights concerning Early Pleistocene cervids and bovids in Europe: dispersal and correlation. In: Kahlke R.D., Maul L.C. \& Mazza P.P.A. (eds.), Late Neogene and Quaternary biodiversity and evolution: Regional developments and interregional correlations. Volume II. Courier Forschungs-Institut Senckenberg, 259, 47-59.

CROITOR R. \& Popescu A. (2011) - Large-sized ruminants from the Early Pleistocene of Leu (Oltenia, Romania) with remarks on biogeographical aspects of the "Pachycrocuta event". N. Jb. Geol. Paläont. Abh., 261, 353-371.

CUVIER G. (1812) - Recherches sur les ossemens fossiles, où l'on rétablit les caractères de plusieurs animaux dont les révolutions du globe ont détruit les especes. Atlas 1-2. Deterville, Paris.

CUVIER G. (1821-1824) - Recherches sur les ossemens fossiles, ou l'on rétablit les caractères de plusieurs animaux dont les révolutions du globe ont détruit les espèces. Five volumes. Dufour et d'Ocagne, Paris.

CUVIER G. (1836) - Recherches sur les ossements fossiles. Tome IX, Paris.

DE GIULI C. (1972) - On the type form of Equus stenonis Cocchi. Palaeont. Ital., 68, 35-49.
Del Campana D. (1913) - I cani pliocenici della Toscana. Palaeont. Ital., 19, 189-254.

Del Campana D. (1914) - La Lycyaena lunensis n.sp. dell'ossario di Olivola (Val di Magra). Palaeont. Ital., 20, 87-104.

Del Campana D. (1915) - Nuove ricerche sui felini del Pliocene italiano. Palaeont. Ital., 21, 233-290

Del Campana D. (1916) - Nuove ricerche sui felini del Pliocene italiano. Palaeont. Ital., 22, 1-33.

Delfino M. \& Bailon S. (2000) - Early Pleistocene herpetofauna from Cava Dell'Erba and Cava Pirro (Apulia, Southern Italy). Herp. J., 10, 95-110.

DELFINO M. \& CHESI F. (2008) - A critical overview of the fossil record and its bearing on the origin of the extant Italian tortoises. Pp. 188-191. In: Corti C. (ed.), Herpetologia Sardiniae. Societas Herpetologica Italica/Edizioni Belvedere, Latina.

Delfino M. \& Szyndlar Z. (2003) - Coluber etruriae Portis, 1890 (Serpentes: Colubridae), a redescription. Neues Jahrb. Geol. Pal. Monatsch., 2003 (2), 65-72.

Delson E., Terranova C.J., Jungers W.L., SARgis E.J., JablonSKI N.G. \& DECHOW P.C. (2000) - Body mass in Cercopithecidae (Primates, Mammalia): estimation and scaling in extinct and extant taxa. Anthropol. Papers Am. Mus. Nat. Hist., 83, 1-159.

Depéret C. \& Mayet L. (1923) - Les Eléphants Pliocenes. Part 2. Ann. Univ. Lyon, n.s. I, 42, II.

Di Stefano G. \& Petronio C. (1998) - Origin and relationships among Dama-like cervids in Europe. Neues Jahr. Geol. Paläont., 207, 37-55

Dominici S. \& Cioppi E. (2012) - Evolutionary theory and the Florence Paleontological collection. Evol. Edu. Outreach, 5, 9-13.

Dong M. (2008) - Nouveau matériel de Leptobos (Smertiobos) crassus (Artiodactyla, Mammalia) du Pléistocène inférieur à Renzidong (Chine de l'Est). Géobios, 41, 355-364.

DUVERNOIS M.P. (1990) - Les Leptobos (Mammalia, Artiodactyla) du Villafranchien d'Europe occidentale. Systématique, évolution, biostratigraphie, paléoécologie. Doc. Lab. Géol. Fac. Sci. Lyon, 113, 1-213.

DuvernoIs M.P. \& Guérin C. (1989) - Les Bovidae (Mammalia, Artiodactyla) du villafranchien supérieur d'Europe occidentale. Géobios, 22 (3), 339-379.

Esu D. \& GHINASsi M. (2012) - The non-marine molluscs of the PlioPleistocene Upper Valdarno Basin (Tuscany, central Italy): depositional enviroments, palaeoecology and biochronology. Ital. J. Geosci., 132, 126-136. doi: 10.3301/IJG.2012.22.

FABRINI E. (1890) - I Machairodus (Meganthereon) del Valdarno Superiore. Boll. R. Com. Geol. It., ser. 3, 1, 1-43.

FAlConer H. (1868) - Paleontological Memoirs and Notes of the late H. Falconer. C. Murchinson, London.

FERRETTI M.P. (1999a) - Enamel structure in the Hyaenid Chasmaporthetes lunensis lunensis from the Late Pliocene of Italy, with implications for feeding behavior. J. Vert. Paleont., 19, 767-770.

Ferretti M.P. (1999b) - Mammuthus meridionalis (Mammalia, Proboscidea, Elephantidae) from the "Sabbie Gialle" of Oriolo (Cava La Salita, Faenza, Northern Italy) and other European late population of southern mammoth. Ecl. Geol. Helv., 92, 503-515.

FERRETTI M.P. \& CROITOR R. (2001) - Functional morphology and ecology of Villafranchian Proboscideans from Central Italy. In: Cavaretta G., Gioia P., Mussi M. \& Palombo M.R. (eds.), The World of Elephants. Proceedings of the 1st International Congress, Rome, 16-20 October. CNR, Roma.

FerRetti M.P. \& DeBruYne R. (2010) - Anatomy and phylogenetic value of the mandibular and coronoid canals and their associated foramina in proboscideans (Mammalia). Zool. J. Linnaean Soc., 161, 391-413

FICCARELLI G. (1979) - The villafranchian machairodonts of Tuscany. Palaeont. Ital., 71, 17-26.

Ficcarelli G., AbBazzi L., Albianelli A., Bertini A., Coltorti M., Magnatti M., Masini F., Mazza P., Mezzabotta C., NapoleoNE G., ROOK L., Rustioni M. \& TORRe D. (1997) - Cesi, an early Middle Pleistocene site in the Colfiorito basin (Umbria-Marchean Apennine). J. Quat. Sci., 12, 507-518.

Fidolini F. \& ANDREETTA A. (2013) - Integrating sedimentological and paleopedological data for paleoenvironmental reconstruction: examples from the Plio-Pleistocene Upper Valdarno Basin 
(Northen Apennines, Italy). Ital. J. Geosci., 132, 149-166. doi: 10.3301/IJG.2012.26.

Fidolini F., Ghinassi M., Magi M., PAPINI M. \& SAGRi M. (2013) The Plio-Pleistocene fluvio lacustrine Upper Valdarno Basin (central Italy): stratigraphy and Basin fill evolution. Ital. J. Geosci., 132, 13-32. doi: 10.3301/IJG.2012.06.

FLEROW K.K. (1952) - Musk deer and deer (in Russian). Fauna of the USSR. Mammalia, 1 (2), 3-255, Moscow-Leningrad.

Forsyth MAJOR C.I. (1877) - Considerazioni sulla fauna dei Mammiferi pliocenici e postpliocenici della Toscana. Mem. Soc. Tosc. Sci. Nat., 3, 202-227.

Forsyth MAJOR C.I. (1881) - Studi sugli avanzi pliocenici del genere Sus. Atti Soc. Tosc. Sci. Nat., Proc. Verb., 2, 227.

Forsyth Major C.I. (1890) - L'ossario di Olivola in Val di Magra (Prov. di Massa e Carrara). Proc. Verb. Soc. Tosc. Sci. Nat., 7, 57-78.

Fortelius M., Mazza P. \& SAla B. (1993) - Stephanorhinus (Mammalia, Rhinocerotidae) of the western European Pleistocene, with a special revision of Stephanorhinus etruscus (Falconer, 1868). Palaeont. Ital., 80, 63-155.

Gallai G. (2006) - Sistematica, Paleoecologia, Paleogeografia dei Suidae fossili italiani. PhD Thesis, Univeristà di Firenze.

GARRIDO G. (2008) - The first record of Leptobos etruscus (FALCONER, 1868) (Bovidae, Artiodactyla, Mammalia) for the Iberian Peninsula (Fonelas P-1, Guadix Basin, Granada). In: Arribas A. (ed.), "Vertebrados del Plioceno superior terminal en el suroeste de Europa: Fonelas P-1 y el Proyecto Fonelas". Cuadernos del Museo Geominero, 10, 489-516.

GEIST V. (1998) - Deer of the World: their Evolution, Behavior and Ecology. Mechanicsburg: Stackpole Books, 416 pp.

Gentili S. \& MAsini F. (2005) - An outline of Italian Leptobos and a first sight on Leptobos aff. vallisarni from Pietrafitta (Early Pleistocene, Perugia). In: Crégut-Bonnoure E. (ed.), "Les ongulés holarctiques du Pliocène et du Pléistocène". Quaternaire, Horssérie, 2, 81-89.

Ghinassi M., Abbazzi L., Esu D., Gaudant J. \& Girotti O. (2005) Facies analysis, stratigraphy and palaeontology (Molluscs and Vertebrates) in the Upper Pliocene sandy flood-basin deposits of the Upper Valdarno Basin (Northern Apennines). Riv. It. Paleont. Strat., 111, 467-487.

Ghinassi M., Fidolini F., Magi M. \& SAgRi M. (2013) - Depositional environments of the Plio-Pleistocene Upper Valdarno Basin (Tuscany, Italy). Ital. J. Geosci., 132, 33-53. doi: 10.3301/IJG.2012.07.

GHINASSI M. \& MAGI M. (2004) - Variazioni climatiche, tettoniche e sedimentazione al passaggio Pliocene Medio-Pliocene Superiore nel bacino del Valdarno Superiore (Appennino Settentrionale). Boll. Soc. Geol. It., 123, 301-310.

Ghinassi M., Magi M., SAgri M. \& Singer B.S. (2004) - Arid climate 2.5Ma in the Plio-Pleistocene Valdarno Basin (Northern Apennines, Italy). Palaeogeogr., Palaeoclimat., Palaeoecol., 207, 37-57.

Gignoux M. (1916) - L'étage Calabrien (Pliocène supérieur marin) sur le versant NE del l'Apennin, entre le Monte Gargano et Plaisance. Bull. Soc. Géol. France, 4, 324-348.

Gliozzi E., Abbazzi L., Argenti P., Azzaroli A., Caloi L., Capasso Barbato L., Di Stefano G., Esu D., Ficcarelli G., Girotti O. Kotsakis T., Masini F., Mazza P., Mezzabotta C., Palombo M.R., Petronio C., Rook L., Sala B., Sardella R., ZanalDA E. \& TORRE D. (1997) - Biochronology of selected mammals, molluscs and ostracods from the middle Pliocene to the late Pleistocene in Italy. The state of the art. Riv. It. Paleont. Strat., 103, 369-388.

GRUBB P. (2000) - Valid and invalid nomenclature of living and fossil deer, Cervidae. Acta Theriol., 45, 289-307.

Guerin C. (1980) - Les rhinocéros (Mammalia, Perissodactyla) du Miocène terminal au Pléistocène supérieur en Europe occidentale. Comparaison avec les espèces actuelles. Doc. Lab. Géol. Lyon, 79 $1-1185$.

Heintz E. (1970) - Les Cervides Villafranchiens de Franse et d'Espagne. Mem. Mus. Natl. Hist. Nat. Sec. C, Sci. Ter., 22, 1-302.

HePtNer V.G. \& TZALKIN V.I. (1947) - Deer of the USSR (in Russian). Transactions on Study of Fauna and Flora of the USSR, 10 (25), 1-176, Moscow.
Hervet S. (2000) - Tortues du Quaternaire de France: critères de détermination, répartitions chronologique et géographique. Mésogée, 58, 3-47.

JABLONSKI N.G. (2002) - Fossil Old World monkeys: the late Neogene radiation. In: Hartwig W.C. (ed.), The Primate Fossil Record. Cambridge University Press, Cambridge, 255-299.

KöHLER M. (1993) - Skeleton and habitat of recent and fossil ruminants. Münch. Geowiss. Abh. (A), 25, 1-88.

Kostopoulos D. (2006) - Greek bovids through time. Hellen. J. Geosci., 41, 141-152.

Kotsakis T. (1980) - Revision des tortues (Emydidae, Testudininidae, Trionychidae) du Plio-Pléistocene de Valdarno supérieur (Toscane, Italie). Quaternaria, 22, 11-37.

Kretzoi M. (1938) - Die Raubtiere von Gombaszog nebst einer Uebersicht der Gesamtfauna. Ann., Mus. Hist. Hung., 31, 88-157.

Kurtén B. \& Werdelin L. (1988) - A review of the genus Chasmaporthetes Hay, 1921 (Carnivora, Hyaenidae). J. Vert. Paleont., 8, 46-66.

Lacombat F. (2007) - Phylogeny of the genus Stephanorhinus in the Plio-Pleistocene of Europe. Hallesches Jahrb. Geowiss., 23, 63-64.

Lacombat F. (2010) - Estudio paleontológico de Stephanorhinus hundsheimensis de Fuente Nueva 3 y de Barranco León 5. In: Toro I., Martínez-Navarro B. \& Agustí J. (eds.), Ocupaciones Humanas en el Pleistoceno inferior y medio de la Cuenca de Guadix-Baza. Junta de Andalucía. Consejería de Cultura. Arqueología Monografías, 237-246.

Lapparent de Broin F. de, Bour R., Parham J.F. \& Perälä J. (2006a) - Eurotestudo, a new genus for the species Testudo hermanni Gmelin, 1789 (Chelonii, Testudinidae). C. R. Palevol., 5, 803-811.

Lapparent de Broin F. DE, Bour R. \& Perälä J. (2006b) - Morphological definition of Eurotestudo (Testudinidae, Chelonii): first part. Ann. Paléont., 92, 255-304.

Lapparent de Broin F. DE, Bour R. \& Perälä J. (2006c) - Morphological definition of Eurotestudo (Testudinidae, Chelonii): second part. Ann. Paléont., 92, 325-357.

LiNDSAY E.H., OPDYKe N.O. \& JoHnson N.M. (1980) - Pliocene dispersal of the horse Equus and late Cenozoic mammalian dispersal events. Nature, 287, 135-138.

Lister A.M. (2011) - The collection of Plio-Pleistocene Proboscideans in the Museum of Florence. In: Monechi S. \& Rook L. (eds.), Il Museo di Storia naturale dell'Università di Firenze. Volume $3^{\circ}$. Le collezioni geologiche e paleontologiche, 259-260.

Lister A.M., Sher A.V., van Essen H. \& WiE G. (2004) - The pattern and process of mammoth evolution in Eurasia. Quat. Int., 126$128,49-64$.

Lyras G., VAN Der GeER A.A.E. \& RoOK L. (2010) - Body size of insular carnivores: evidence from the fossil record. J. Biogeogr., 37, 1007-1021.

MADE J. VAN DER (1999) - On Euraxis, on the rules of ICZN, on methodology. Neues Jahrb. Geol. Paläont., 1999 (11), 676-678.

MARTínez-NAVARro B. \& RooK L. (2003) - Gradual evolution in the African hunting dog lineage: Systematic implications. C.R. Paleovol., 2, 695-702.

Martínez-Navarro B., Pérez-Claros J.A., Palombo M.R., Rook L. \& Palmovist P. (2007) - The Olduvai's buffalo Pelorovis and the origin of Bos. Quat. Res., 68, 220-226.

MASINI F. (1989) - I Bovini Villafranchiani dell'Italia. Vol. 1, 2. PhD Dissertation in Palaeontology, Modena and Florence University.

Mazza P., Martini F., Sala B., Magi M., Colombini M.P., Giachi G., Landucci F., Lemorini C., Modugno F. \& Ribechini E. (2006) A new Palaeolithic discovery: tar-hafted stone tools in a European Mid-Pleistocene bone-bearing bed. J. Archaeol. Sci., 33, 1810-1818.

Mazza P. \& Rustioni M. (1992) - Morphometric revision of the Eurasian species Ursus etruscus Cuvier. Palaeont. Ital., 79, 101-146.

Mazza P., Sala B. \& Fortelius M. (1993) - The small latest Villafranchian (late Early Pleistocene) rhinoceros from Pietrafitta (Perugia, Umbria, CentraI Italy) with notes on the Pirro and Westerhoven rhinoceroses. Palaeont. Ital., 80, 25-50.

McGowran B., Berggren B., Hilgen F., Steininger F., Aubry M.P., Lourens S. \& VAN Couvering J. (2009) - Neogene and 
Quaternary coexisting in the geological time scale: the inclusive compromise. Earth Sci. Rev., 96, 249-262.

MerLa G. (1949) - I Leptobos Rütimeyer Italiani. Palaeont. Ital., 16, 41-155.

Mlíkovský J. (2002) - Cenozoic Birds of the World. Part I. Europe. Praha: Ninox Press.

MŁYNARSKI M. (1962) - Notes on the amphibians and reptilian fauna of the Polish Pliocene and early Pleistocene. Acta Zool. Cracov., 7, 177-196.

Mourer-Chauviré C. (1975) - Les oiseaux du pléistocène moyen et superieur de France. Doc. Lab. Géol. Fac. Sci. Lyon, 64 (1-2), $1-624$

Napoleone G., Albianelli A., Azzaroli A. \& Mazzini M. (2001) The Poggio Rosso locality calibrated to the end-Pliocene and its significance for dating the late Villafranchian mammal faunas of the Upper Valdarno, Central Italy. Riv. It. Paleont. Strat., 107, 287-296.

NAPOLEONE G. \& Azzaroli A. (2002) - A collection of fossil vertebrates from the Upper Valdarno (central Italy) calibrated in the end Pliocene to span 220,000 years across the Olduvai magnetochron. Riv. It. Paleont. Strat., 108, 479-492.

Napoleone G., Albianelli A., Azzaroli A., Bertini A., Magi M. \& Mazzini M. (2003) - Calibration of the upper Valdarno basin to the plio-pleistocene for correlating the Apennine continental sequences. Il Quaternario, 16, 131-166.

Nesti F. (1808) - Di alcune ossa fossili di mammiferi che s'incontrano nel Valdarno. Ann. Imp. Mus. Firenze, 1, 12 pp.

Nesti F. (1825) - Lettere sopra alcune ossa fossili del Valdarno non paranco descritte. Nuovo Giorn. Lett., 11, 195-216.

PALOMbo M.R. \& FerRetTi M.P. (2005) - The Italian elephant fossil record: knowledge, problems and perspectives. Quat. Int., 126-128, 107-136.

PARETO L. (1865) - Note sur les subdivisions que l'on pourrait établir dans les terrains tertiaires de l'Apennin septentrional. Bull. Soc. Géol. France, 22, 210-277.

Petronio C. (1979) - Dama nestii eurygonos Azz. di Capena (Roma). Geol. Romana, 18, 105-125.

Pohlig H. (1885) - Üeber eine Hipparionen-Fauna von Maragha in Nord-Persien, über fossile elephanten reste Caucasien und Persien und über die resultate einer Monographie der fossilen elephanten Deutchlands und Italiens. Zeitsch. Deutsch. Geol. Gesell., 37, 1022-1027.

PORTIS A. (1889) - Gli ornitoliti del Valdarno superiore e di alcune altre località plioceniche di Toscana. Mem. R. Ist. Stud. Sup. Prat. (Firenze), 1889, 1-20.

PorTIS A. (1890) - I Rettili pliocenici del Valdarno superiore e di alcune altre località plioceniche di Toscana. Le Monnier, Firenze.

Portis A. (1896) - Contribuzioni alla storia fisica del bacino di Roma e studii sopra l'estensione da darsi al Pliocene superiore. II. Roma.

Pradella C. \& RooK L. (2007) - Mesopithecus (Primates, Cercopithecoidea) from Villafranca d'Asti (Early Villafranchian; NW Italy) and palaeoecological context of its extinction. Swiss Journal of Geosciences, 100, 145-152.

Regalia E. (1902) - Sette uccelli pliocenici del Pisano e de Valdarno superiore. Palaeont. Ital., 8, 219-238.

Ricci A. (1901) - L'Elephas primigenius Blum. nel Post-Pliocene della Toscana. Palaeontogr. It., 7, 121-129.

Ristori G. (1897) - L'orso pliocenico del Valdarno e di Olivola. Palaeont. Ital., 3, 15-76.

Rook L. (2009) - The Italian fossil primate record: an update and perspective for future research. Boll. Soc. Paleont. It., 48, 67-77.

Rook L. (2012) - Basel-Tuscany, a long-lasting link. Swiss J. Palaeont., $131,7-9$
Rook L. \& Alba D.M. (2012) - The pioneering paleoprimatologist Charles Immanuel Forsyth Major (1843-1923) and a Mesopithecus tooth from an unrecorded locality of Italy (?Casino Basin) in the Basel Naturhistorisches Museum. Boll. Soc. Paleont. It., $\mathbf{5 1}, 1-6$.

RooK L. \& ANGELONE C. (2013) - Just a few: rodents and lagomorphs in the Plio-Pleistocene fossil record of the Upper Valdarno Basin. Ital. J. Geosci., 132, 98-103. doi: 10.3301/IJG.2012.27.

Rook L., Ferretti M.P., Arca M. \& Tuveri C. (2004) - Chasmaporthetes melei n.sp., an endemic Hyaenid (Carnivora, Mammalia) from the Monte Tuttavista fissure fillings (Late Pliocene to Early Pleistocene; Sardinia, Italy). Riv. It. Paleont. Strat., 110 639-646.

RoOK L. \& MARTínez-NAVARRo B. (2010) - Villafranchian: The long story of a Plio-Pleistocene European large mammal biochronologic unit. Quat. Int., 219, 134-144.

Rook L., Mottura A. \& Gentili S. (2001) - Fossil Macaca remains from $R D B$ quarry (Villafranca d'Asti, Italy): new data and overview. J. Hum. Evol., 40, 187-202.

Rook L. \& O'Higgins P. (2005) - A comparative study of adult facial morphology and its ontogeny in the fossil macaque Macaca majori from Capo Figari, Sardinia, Italy. Folia Primatol., 76, 151-171.

ROOK L. \& TORRE D. (1996) - The wolf event in western Europe and the beginning of the Late Villafranchian. N. Jahrb. Geol. Paläont. Mh., 8, 495-501.

Rustioni M. (1992) - On Pliocene tapirs from France and Italy. Boll. Soc. Paleont. It., 31, 269-294.

RÜTIMEYER L. (1878) - Die Rinder der Tertiär-Epoche nebst Vorstudien zu einer Natürlichen Geschichte der Antilopen. Abh. Schweiz. Paläont. Gesell., 4-5, 1-208.

SANChIZ B. (1998) - Salientia. In: Handbuch der PaläoherpetologieEncyclopedia of Paleoherpetology. Part 4. Verlag Friedrich Pfeil, München.

Shaub S. (1949) - Révision de quelques Carnassieres Villafranchiens du Niveau des Etouaires (Montagne de Perrier, Puy-du-Dôme). Eclog. Geol. Helv., 42, 492-506.

SPENCER L. (1995) - Morphological correlates of dietary resource partitioning in the African Bovidae. J. Mamm., 76 (2), 448-471.

Szalay F. \& Delson E. (1979) - Evolutionary History of the Primates. Academic Press, New York.

Torre D. (1985) - Mimomys savinii and Arvicola cantiana in the Upper Valdarno (Italy). Eclogae geol. Helv., 78, 715-718.

Torre D., Abbazzi L., Bertini A., Fanfani F., Ficcarelli G., MasiNI F., MAzZA P. \& RooK L. (2001) - Structural changes in Italian Late Pliocene-Pleistocene large mammal assemblages. Boll. Soc. Paleont. It., 40, 303-306.

Tyrberg T. (1988) - Pleistocene birds of the Palearctic: a catalogue. Publ. Nuttall Ornithological Club, No. 27.

Valli A.M.F. \& Palombo M.R. (2005) - Le régime alimentaire du Cervidae (Mammalia) Eucladoceros ctenoides (Nesti 1841) reconstitué par la morphologie du crâne et par l'usure dentaire. Eclogae geol. Helv., 98, 133-143.

VAn Couvering J., Aubry M.P., Berggren W.B., Gradstein F.M., Hilgen F., Kent D.V., Lourens S. \& McGowran B. (2009) What, if anything, is Quaternary?. Episodes, 32 (2), 1-2.

Vos J. DE, Mol D. \& Reumer J.W.F. (1995) - Early Pleistocene Cervidae (Mammalia, Artyodactyla) from the Oosterschelde (the Netherlands), with a revision of the cervid genus Eucladoceros Falconer, 1868. Deinsea, 2, 95-121.

Weithofer A. (1890) - Die fossilien Proboscidier des Arnotales in Toskana. Beitr. Palaeont. Oesterr.-Ungarns, 8, 107-268.

WiLLIAMS H.S. (1901) - The discrimination of time values in geology. J. Geol., 9, 570-585. 